\title{
The Wyatt Case: Implementation of a Judicial Decree Ordering Institutional Change*
}

Recent lawsuits asking federal courts to mandate large scale institutional change have drawn into question the traditional role of a court in litigation. This role usually terminated with a judicial decree of rights between the parties, and an order directing the parties to perform certain acts. The actual performance of those acts has customarily taken place without the participation of the court. However, in several recent cases mandating institutional change-particularly in prisons and mental hospitals-federal courts have assumed a more active role in the implementation of their orders to assure that their decrees become more than paper pronouncements.

This Note focuses on one recent case in which the court became involved in the implementation of the institutional changes it had decreed. In Wyatt v. Stickney ${ }^{1}$ United States District Judge Frank M. Johnson, Jr., of the Middle District of Alabama ruled that mentally impaired persons confined in Alabama state hospitals were being denied a constitutional "right to treatment," 2 and ordered a range of

* The research for this Note was funded in part by the Mental Health Law Project which is affiliated with the Center for Law and Social Policy, Washington, D.C. The Center represented several national mental health organizations as amici in the litigation discussed in this Note. The views expressed in this Note are those of the authors, not of the Project or the Center.

1. 344 F. Supp. 373, 344 F. Supp. 387 (M.D. Ala. 1972), enforcing 325 F. Supp. 781, 334 F. Supp. 1341 (M.D. Ala. 1971), aff'd in part, remanded in part, decision reserved in part sub nom. Wyatt v. Aderholt, 503 F.2d 1305 (5th Cir. 1974). The Fifth Circuit opinion affirmed the district court's holding that the Constitution guarantees a right to treatment to civilly committed mental patients, that the suit was not barred by the Eleventh Amendment, that the right to treatment could be implemented through judicially manageable standards, and that the granting of relief did not invade a province of decision making reserved to the legislature. Id. at 1312-16. Stating that the issue was premature, the Fifth Circuit reserved decision on whether the district court could alter the state budget or take other steps to finance the right to treatment should the state fail to take appropriate action. Id. at 1318. A decision on the award of attorneys' fecs was also rescrved so that the issue could be decided with other pending cases. Id. at 1319 .

2. The district court and the Fifth Circuit both found that the Duc p'rocess Clause of the Fourteenth Amendment guarantecs mental patients a "right to reccive such individual treatment as will give each of them a reasonable opportunity to be cured or to improve his or her mental condition," $325 \mathrm{~F}$. Supp. at 784 , and a right to "such individual habilitation as will give each of them a realistic opportunity to lead a more useful and meaningful life and to return to society." $344 \mathrm{~F}$. Supp. at 390 . The Fifth Circuit's affirmance of Wyatt relied primarily on its earlier decision in Donaldson $v$. O'Connor, 493 F.2d 507 (5th Cir.), cert. granted, 95 S. Ct. 171 (1974), which it summarized as follows:

In Donaldson, we held that civilly committed mental patients have a constitutional right to such individual treatment as will help each of them to be cured or to improve his or her mental condition. We reasoned that the only permissible justifications for civil commitment, and for the massive abridgements of constitutionally protected liberties it entails, were the danger posed by the individual committed to himself or to others, or the individual's need for treatment and care. We held that where 
institutional changes in three state mental hospitals. For each institution, he appointed a Human Rights Committee ${ }^{3}$ to oversee the implementation of the changes and to act as the "eyes and ears" of the court to protect the constitutional rights of the institution's residents."

While the "right to treatment" doctrine and its development in Wyatt have been the subjects of extensive comment, ${ }^{5}$ the implementation process has been largely ignored in the literature. Wyatt provides a useful case study for examining the mechanisms available to courts to achieve the implementation of judicial decrees ordering institutional changes, and the role a court can assume in the implementation process. To detail the implementation process in Wyatt, this Note will draw on interviews with persons on all sides of the litigation, ${ }^{6}$ the

the justification for commitment was treatment, it offended the fundamentals of due process if treatment were not in fact provided; and we held that where the justification was the danger to self or to others, then treatment had to be provided as the quid pro quo society had to pay as the price of the extra safety it derived from the denial of individuals' liberty.

503 F.2d at 1312. For a list of some of the extensive literature on the "right to treatment" see note 5 infra.

3. 344 F. Supp. at 378,$386 ; 344$ F. Supp. at $392,407$.

4. For a discussion of other cases involving similar implementation devices, see pp. 1344-46 infra.

5. See, e.g., Drake, Enforcing the Right to Treatment: Wyatt v. Stickney, 10 AM. CRIM. L. REv. 587 (1972) (co-counsel for plaintiffs discusses the early stages of the lawsuit concerning Bryce Hospital); Developments in the Law-Civil Commitment of the Mentally Ill, 87 Harv. L. REv. 1190, 1337-42 (1947) [hereinafter cited as Developments-Civil Commitment] (discusses the formulation of the decree and implementation); Note, Implementing the Right to Treatment for Involuntarily Confined Mental Patients: Wyatt v. Stickney, 3 N.M.L. REv. 338 (1973) (discusses possible sanctions to enforce the right to treatment); Commentary, A State Mental Institution is Constitutionally Required to Provide Adequate Medical Treatment for Patients Involuntarily Committed, 23 ALA. L. REv. 642 (1971) (discusses the early stages of the case); Case Comment, Wyatt v. Stickney and the Right of Civilly Committed Mental Patients to Adequate Treatment, 86 HARv. L. Rev. 1282 (1973) [hereinafter cited as Wyalt Case Comment] (discusses the issuance of the decree).

For discussion of the "right to treatment," see, e.g., Birnbaum, The Right to Treatment, 46 A.B.A.J. 499 (1960); Rothman, Decarcerating Prisoners and Mental Patients, I Civ. LIB. REv. 8 (1973); Schwitzgebel, Right to Treatment for the Mentally Disabled: The Need for Realistic Standards and Objective Criteria, 8 HARv. Civ. Rights-Civ. Lib. L. Rev. 513 (1973); Symposium, Observations on the Right to Treatment, 10 Due. L. REv. 553 (1972); Symposium, The Right to Treatment, 57 Geo. L.J. 673 (1969); Symposium, The Mentally Ill and the Right to Treatment, 36 U. CHI. L. REv. 742 (1969); DevelopmentsCivil Commitment, supra, at 1316-57; Note, The Rights of the Mentally Ill During Incarceration: The Developing Law, 25 U. FLA. L. REV. 494 (1973); Note, The Nascent Right to Treatment, 53 VA. L. REv. 1134 (1967); Note, Civil Restraint, Mental Illness, and the Right to Treatment, 77 YALE L.J. 87 (1967).

6. Interviewed were:

Attorneys: George W. Dean, counsel for plaintiffs, Montgomery, Ala., Aug. 29, 1974; Ira DeMent, U.S. Attorney for the Middle District of Alabama, in Montgomery, Ala., Aug. 19, 1974; Jack Drake, co-counsel for plaintiffs, in Tuscaloosa, Ala., Aug. 22, 1974; Charles Halpern, counsel for several national mental health organizations as amici curiae, in Washington, D.C., May 17, 1974 (Center for Law and Social Policy); Bob Humphries, Assistant Attorney General of Alabama, in Montgomery, Ala., Aug. 19, 1974; Kenneth Vines, Assistant U.S. Attorney for the Middle District of Alabama, in Montgomery, Ala., Aug. 20, 1974. Defendants, Administrators and Staff: Peter Blouke, former Superintendent of Partlow State School and Hospital, in Tuscaloosa, Ala., Aug. 22, 1974; Richard E. Buckley, then Superintendent of Partlow State 
official legal papers filed with the court by all parties, ${ }^{7}$ official progress reports, ${ }^{8}$ and informal letters and memoranda.

\section{The Emerging Importance of Implementation}

The judiciary has generally limited the scope of its judgments in order to avoid extensive involvement in implementing large scale institutional change. This was a result of the principle that "a court of equity will not issue an unenforceable decree of injunction,"9 and of the assumption that only limited techniques of enforcement, such as contempt, were available to the court.

Because the only injunctions which could apparently be enforced by contempt were preventive injunctions, which prohibit or compel the performance of discrete, easily defined acts, ${ }^{10}$ those were the only injunctions issued. ${ }^{11}$ The problem of implementation rarely arose.

School and Hospital, in Tuscaloosa, Ala., Aug. 21, 26, 1974; Rcv. Lou Scales, Chaplain of Partlow State School and Hospital, in Tuscaloosa, Ala., Aug. 28, 1974; Stonewall 3. Stickncy, M.D., former Commissioner of Mental Health Board of Alabama, in Montgomery, Ala., Aug. 20, 1974. Bryce Human Rights Commillec Members: Bert Bank, Chairperson, in Tuscaloosa, Ala., Aug. 26, 1974; Babs Heilpern, in Montgomery, Ala., Aug. 20, 1974 (telephonc); Alberta Murphy, in Tuscaloosa, Ala., Aug. 27, 1974; John T. Wagnon, in Montgomery, Ala., Aug. 19, 1974. Parllow Human Rights Committee Members: Harriet Tillman, Chairperson, in Birmingham, Ala., Aug. 24, 1974; Marvin B. Dinsmore, in Tuscaloosa, Ala., Aug. 22, 1974; Rev. Robcrt Kecver, in Tuscaloosa, Ala., Aug. 22, 1974; Andrew Lorincz, M.D., in Birmingham, Ala., Aug. 24, 25, 1974; John Mathews, in Montgomery, Ala., Aug. 18, 1974; Rev. James Pernell, in Tuscaloosa, Ala., Aug. 28, 1974; James "Sumshine" Smith, in Tuscaloosa, Ala., Aug. 22, 1974. Others: Alfred Baumeister, professor of psychology, University of Alabama, in Tuscaloosa, Ala., Aug. 26, 1974; Norman Ellis, professor of psychology, University of Alabama, in Tuscaloosa, Ala., Aug. 26, 1974; Ray Fowler, Chairperson of University of Alabama Psychology Department, in Tuscaloosa, Ala., Aug. 22, 1974; Harold Martin, Editor and Publisher of the Montgomery AdvertiserJournal, in Montgomery, Ala., Aug. 20, 1974.

[Interviews are hereinafter cited by the name of the person interviewed.]

7. The legal papers filed with the court by all partics were made available by the Center for Law and Social Policy, Washington, D.C. See note 49 infra. Unless otherwise indicated, all legal papers cited are from Wyatt $v$. Stickney (district court docket on filc with Yale Law Journal).

8. Progress reports filed with the district court are cited according to the titles which appear on the reports. Reports of regular bi-weckly meetings of the Partlow Human Rights Committee are cited as PHRC Report.

9. Hearne v. Smylie, 225 F. Supp. 645,655 (D. Idaho), rev'd per curiam, 378 U.S. 563 (1964); Developments in the Law-Injunctions, 78 HARv. L. Rev. 994, 1012 (1965).

10. The phrase "preventive injunctions" is adopted from O. Fiss, InJuncrions 1 (1972). Fiss distinguishes among three types of injunctions-preventive, regulatory, and structural. A "regulatory" injunction, in Fiss's formulation, is one "where the court puts a general prohibition in an injunction and attempts to use the injunction to regulate a party's behavior over a long period of time," while a "structural injunction" is one "where the court attempts to use the injunction as a device for altering or reorganizing some institutional arrangement." Id. The distinction between "preventive" and "structural" injunctions is used in this Note, but the separate category of "regulatory" injunctions is not. While the difference between preventive and structural injunctions is based on the substantive goal of the injunction, the distinction between these two types and regulatory injunctions is based on the duration of the injunction. "Regulatory" injunctions can therefore be divided entirely into the other two categories.

11. The question of whether the court can fashion adequate relief is one of the three aspects of the traditional concept of "justiciability"-together with whether judicially 
This practice had a particularly harsh application in suits dealing: with conditions in prisons and mental hospitals - "total" or "closed institutions,"12 the characteristics of which made preventive injunctions $^{13}$ or monetary damages ${ }^{14}$ inadequate to remedy unconstitutional conditions. ${ }^{15}$ Several characteristics of these institutions deserve mention. First, because the institutions are total, they

discoverable and manageable standards exist by which the court can measure the rights and obligations of the parties, and whether judicial resolution of the controversy would be an improper assumption of a task more appropriately done by the executive or the legislature. See Powell v. McCormack, 395 U.S. 486, 518-19 (1969); Baker v. Carr, 369 U.S. $186,198,217,236$ (1961); Iyatt Case Comment, supra note 5, at 1296. While this Note focuses specifically on implementation, each of the other aspects of justiciability also bears on the issue of whether effective relief can be given. Manageable standards are necessary not only to pronounce the parties' rights and to formulate a judicial decrec, but also to determine whether the decree is being obeyed, an essential part of implementation. Due respect for the executive and legislature (and also comity between the federal and state governments) is not simply an abstract concept which propriety dictates the court should follow, but rather is an intensely practical aspect of implementation. If agencies of the state executive branch, as defendants in a suit, believe that the court has disregarded principles of either the separation of powers or federal-state relations, the court's ability to effectuate adequate relief will be diminished greatly. See note 15 infra.

12. See E. Goffaran, Asylums: Essays on the Social Situation of Mental Patients AND OTHER INMATES 4-5 (1961):

Every institution captures something of the time and interest of its members and provides something of a world for them; in brief, every institution has encompassing tendencies. When we review the different institutions in our Western society, we find some that are encompassing to a degree discontinuously greater than the ones next in line. Their encompassing or total character is symbolized by the barrier to social intercourse with the outside and to departure that is often built right into the physical plant, such as locked doors, high walls, barbed wire, cliffs, water, forests, or moors. These establishments I am calling total institutions....

Goffman lists five types of "total institutions": those which care for persons who are both incapable and harmless, such as homes for the aged; those which care for persons who are incapable and unintentionally harmful, such as mental hospitals; those used to confine persons who are intentionally dangerous, such as prisons; those established to further the performance of some task, such as army barracks; and those designed as retreats from the world, such as monasteries. Id. See generally D. Bazelon, Law and the Future of the Closed Institution (unpublished paper delivered at Yale Law School Sesquicentennial Convocation, Nov. 1, 1974) (on file with Yale Law Journal) (referring to prisons and mental hospitals as "closed institutions").

13. Preventive injunctions have been issued to redress specific deprivations of constitutional rights in prisons. See, e.g., Procunier v. Martinez, 94 S. Ct. 1800 (1974) (mail censorship).

14. Monetary damages have been awarded to individuals to redress injuries suffered in closed institutions. Donaldson v. O'Connor, $493 \mathrm{~F} .2 \mathrm{~d} 507$ (5th Cir.), cert. granted, $95 \mathrm{~S}$. Ct. 171 (1974); Whitree v. State, 56 Misc. 2d 693, 290 N.Y.S.2d 486 (C.t. Cl. 1968). But it is speculative whether such a remedy will have any effect in improving conditions in the institution. Monetary awards are also of little, if any, value to discharged residents, who may be unable to undo the harm caused by the improper conditions of their confinement.

15. In addition to the ineffectiveness of preventive injunctions, courts also hesitated to enter this area because the institutions are run by the exccutive branch of the government, and because any court orders which require the expenditure of additional funds arguably invade the province of the legislature. However, neither of these considerations has proved to be an obstacle. Courts are no longer reluctant to review the constitutionality of executive action or to issue orders which indirectly require the expenditure of state funds to bring the state into compliance with constitutional standards. This principle has become so widely accepted that in Morales v. Turman, 383 F. Supp. 53, 59 (E.D. Tex. 1974), Judge Justice dismissed as "frivolous" a contention that an order to remedy unconstitutional conditions in correctional facilities for youths contravened the Eleventh Amendment and the separation of powers doctrine. See generally Edelman $v$. 
can readily alter the terms of a patient's confinement. A patient who is kept in custodial confinement may be shifted to a different unit during the pendency of a hearing; granted a conditional release, or have his treatment strategy changed. ${ }^{16}$

While preventive injunctions may be effective to correct individual, discrete abuses in institutions which generally comport with constitutional standards, ${ }^{17}$ they will be inadequate if the institutions contain widespread, systemic violations of constitutional rights. By the time an injunction is issued, the specific constitutional abuse complained of might have ceased, only to be replaced by other illegal acts not covered by the injunction. Second, those likely to be damaged by the institution's wrongful acts, and therefore most likely to be plaintiffs in litigation, are often under the control of the institution and sometimes are incompetent. This makes it difficult for them to find out what their legal rights are, obtain legal assistance, and seek preventive injunctions on their own behalf. ${ }^{18}$ It is also difficult to obtain informa-

Jordan, 415 U.S. 65l, 667-68 (1974); Hawkins v. Town of Shaw, 437 F.2d 1286, 1292 (5th Cir. 1971) (equalization of municipal services); Doe v. General Hosp., 434 F.2d 427, 432.33 (D.C. Cir. 1970) (hospital services for indigents); Jackson v. Bishop, 404 F.2d 571, 580 (8th Cir. 1968) (cruel and unusual punishment in prisons); Mills v. Board of Educ., $348 \mathrm{~F}$. Supp. 866 (D.D.C. 1972) (provision of public education to handicapped children); Inmates of Boys' Training School v. Affleck, 346 F. Supp. 1354 (D.R.I. 1972) (provision of adequate facilities and trained personnel at juvenile corrections institution); Brenneman v. Madigan, 343 F. Supp. 128 (N.D. Calif. 1972) (provision of greater facilities for pretrial detainces); Holt v. Sarver, 309 F. Supp. 362, 385 (E.D. Ark. 1970), aff'd, 442 F.2d 304 (8th Cir. 1971) (cruel and unusual punishment in prisons); United States v. Alsbrook, 336 F. Supp. 973 (D.D.C. 1971) (construction of youth treatment facility). But see Burnham v. Department of Pub. Health, 349 F. Stpp. 1335 (N.D. Ga. 1972), rev'd, 503 F.2d 1319 (5th Cir. 1974), which was consolidated for argument in the Fifth Circuit with Wyatt. In its Wyatt opinion, the Fifth Circuit rejected the Burnham district court's holding that a right to treatment suit contravened the Eleventh Amendment.

States have generally complied with this type of judicial decree, and therefore most of these cases do not confront the question of what measures the court will take to enforce the order which requires the expenditure of state funds. See Griffin v. County School Bd. 377 U.S. 218, 233 (1964); Note, Enforcement of Judicial Financing Orders: Constitutional Rights in Search of a Remedy, 59 GEo. L.J. 393 (1970); Wyall Case Comment, supra note 5 , at 1301 . One means suggested by the plaintiffs in Wyatt to finance the implementation of the decree was a judicial sale of the extensive land holdings of the Alabama Mental Health Board. The defendants opposed this measure, and the court never took action on the request. 344 F. Supp. at 377 .

16. Halpern, A Practicing Lawyer Views the Right to Treatment, 57 GEo. L.J. 782, 799 (1969). Such a change in an individual plaintiff's confinement will moot an individual plaintiff's lawsuit but not a class action. See, e.g., Sosna v. Iowa, 95 S. Ct. 553, 556-59 (1975); Richardson v. Ramirez, 94 S. Ct. 2655 (1974); Roe v. Wade, 410 U.S. 113 (1973).

17. Preventive injunctions, while less suitable for the reform of institutional defects, will play a continual role in ensuring adequate treatment and proper classification of individual mental patients confined in institutions which, on the whole, are run in a constitutional manner. As Chief Justice Flaschner of the District Courts of Massachusetts commented, "the individual case may be more typical of the right to treatment artillery to be faced by most judges, particularly in the state courts." Flaschner, Legal Rights of the Mentally Handicapped: A Judge's Viewpoint, 60 A.B.A.J. 1371,1374 (1974).

18. See Morales v. Turman, 383 F. Supp. 53 (E.D. Tex. 1974) (broad structural changes ordered in reformatories run by the Texas Youth Council). Before the constitutional 
tion about the conditions within the institution, which prevents persons on the outside-such as friends or relatives of residents-from identifying abuses and obtaining assistance for the residents. Moreover, judicial cvaluation of institutional conditions, practices, and procedures is impeded by a professed expertise on the part of the institution, ${ }^{19}$ so that a court considering whether to issue a preventive injunction against particular acts may not be qualified to examine a claim that the acts are necessary as part of a comprehensive professional program. Finally, a judge may be unable to penetrate the institutional bureaucracy to determine what is causing the unconstitutional conditions and how they might be corrected. A preventive injunction may thus prove ineffective because the administrators called upon to eliminate the abuses either do not have sufficient control within the institution or cannot fix responsibility within their own institutional bureaucracy.

When courts moved toward remedying problems within prisons and mental hospitals, these characteristics of closed institutions influenced the form of the judicial orders issued and the techniques of implementation relied upon. In devising techniques for implementation of institutional change, courts have sought to make the judicial process more available to the institution's residents, thus partially insulating them from the control of the institution. Courts have also sought means to obtain independent, reliable information about what is going on in the institution, to subject the institution's professed expertise to the scrutiny of other experts, and to "open up" the institutional bureaucracy by giving staff at all levels access to the court.

To accomplish this, the judiciary has drawn on its authority to fashion "appropriate instruments required for the performance of [its] duties," 20 including the power to appoint judicial officers. ${ }^{21}$ In addi-

issues could be adjudicated, it was necessary for the court to issue an order protecting the rights of incarcerated youths to confer in private with their attorncys. Morales v. Turman, 326 F. Supp. 677 (E.D. Tex. 1971).

19. This professed institutional expertise, combined with the fact that the institutions are run by the exccutive branch of the govermment, led courts to abide by the "hands-off" doctrine, an extreme rule of judicial deference which virtually immunized the correctional system from judicial scrutiny. See, e.g., Bethca v. Crouse, 417 F.2d 504, 505.06 (10th Cir. 1969). See generally Turner, Establishing the Rule of Law in Prisons: A Manual for Prisoners' Rights Liligation, 23 StaN. L. REv. 473 (1971); Note, Decency and Faimess: $A n$ Emerging Judicial Role in Prison Reform, 57 VA. L. Rev. 841 (1971); Note, Beyond the Ken of the Courts: A Critique of Judicial Refusal to Review the Complaints of Convicts, 72 YALE L.J. 506 (1963).

20. Ex parte Peterson, 253 U.S. 300, 312 (1920). The authority of fedcral courts to appoint masters derives from both their inherent powers, id, and FED. R. CIv. P. 53.

21. Another area of law in which courts have used judicially appointed officers to aid in the implementation of their decrees is employment discrimination. Under Title VII of the 1964 Civil Rights Ict, 42 U.S.C. $\$ 2000 \mathrm{c}$ (1970), scveral courts have appointed "administrators" or committces, responsible to the court, to develop and then supervise 
tion to employing traditional remedies, such as the appointment of masters ${ }^{22}$ or receivers, ${ }^{23}$ courts have fashioned several new ones.

One novel judicial approach has combined the factfinding role of the traditional master and the supervisory role of the traditional receiver to form a "hybrid" master to aid in the implementation of structural injunctions. For example, in Pennsylvania Association for Retarded Children $v$. Pennsylvania, ${ }^{2+}$ two masters, one an attorney and one a special educator, were charged with both evaluating and implementing a plan drafted by the state to provide a suitable public education for retarded children. ${ }^{25}$ In Knight $v$. Board of Education, ${ }^{20}$ the court, after ruling that the school must provide appropriate educational opportunities for suspended students, appointed a three member "Masters Committee of Educational Experts" to enforce the order by hearing complaints of individual suspended students. ${ }^{27}$

the implementation of a program to eliminate discrimination in employment. Sec generally Harris, The Tille VII Administrator: A Case Study in Judicial Flexibility, 60 CorNele L. Rev. 53 (1974).

22. Masters are primarily, and were originally, fact-finders for the court, appointed when factual issues are highly complicated or require special expertise for evaluation. Ransom v. Winn, 59 U.S. (18 How.) 295 (1855) (value produce); Wilson v. Homestead Valve MIf. Co., 217 F.2d 792 (3d Cir. 1954), cert. denied, 349 U.S. 916 (1955) (compute damages for breach of contract); Pallma v. lox, 182 F.2d 895 (2d Cir. 1950) (compute damages); Spaeth v. Journal Printing Co., 139 F. Supp. 188 (D. Alas. 1956) (audit books). Masters have also been given responsibility by courts to provide aid in procedural matters. E.g., First Iowa Hydro Elec. Coop. v. Iowa-Illinois Gas \& Elec. Co., 245 F.2d 613 (8th Cir.), cert. denied, 355 U.S. 871 (1957) (supervise discovery in antitrust suit); Schwimmer i: United States, 232 F.2d 855 (8th Cir.), cert. denied, 352 U.S. 833 (1956) (admissibility of evidence); Motley, Green, \& Co. v. Detroit Steel \& Spring Co., 174 I. 734 (C.C.S.D.N.Y. 1909); Waldo Theatre Corp. v. Dondis, I F.R.D. 591 (S.D. Me. 1941) (supervise discovery); Stentor Elec. Mfg. Co. v. Klaxon Co., 28 F. Supp. 665 (D. Del. 1939) (admissibility of evidence). See generally Kaufman, Masters in the Federal Courls: Rule 53, 58 Colum. L. REV: 452 (1958).

23. Receivers, in contrast to masters, are primarily "supervisory" rather than "advisory" officials. A receiver is a court official designated to hold, manage, or liquidate property when that property is threatened with irreparable harm. Reccivership is warranted when the party that has been in control of the property or organization in question is grossly mismanaging it, or when the management is so divided that the operation of the organization has been brought to a standstill. For a comparison of the traditional remedies of masters and reccivers, see Note, Monitors: $A$ New Equitable Remedy?, 70 YaLe L.J. 103, 106-13 (1960).

The distinction between masters and receivers is sometimes blurred. For cxample, courts have appointed special masters to supervise corporate and union elections, after finding that supervision by the organization's officers would bias the result. See, e.g., Schonfeld v. Raftery, 271 F. Supp. 128 (S.D.N.Y.), aff'd, 381 F.2d 446 (2d Cir. 1967); Bartlett v. Gates, 118 F. 66 (C.C. Colo. 1902); Summers, Judicial Regulation of Union Elections, 70 YaLE L.J. 1221, 1253-56 (1961). These "special masters" were, in effect, limited receivers with specific responsibility to supervise the election. The receivership was limited because there was no charge of gross mismanagement of the organization in general, simply gross mismanagement of the impending election.

24. 343 F. Supp. 279 (E.D. Pa. 1972) (consent decrec). See generally Kirp, Buss \& Kuxil. off, Legal Reform of Special Education: Empirical Sludies and Procedural Proposals, '62 Calif. L. Rev. 40, 58-82 (1974).

25. 343 F. Supp. at 288.

26. 48 F.R.D. 115 (E.D.N.Y. 1969).

27. A "hybrid" master has also been used in at least one case involving a claim of "cruel and unusual punishment" in a prison. Some time after determining that the 
Another new implementation technique used by the courts has been the assignment of monitors. Unlike the "hybrid" masters, who are delegated some of the direct responsibility for implementing the court's order, monitors have been appointed simply to observe the implementation process and report their observations to the court. They have been used when the primary impediment to implementation is the inability of the court and the plaintiffs to obtain accurate information about what is occurring within the institution. For example, in Gates $v$. Collier, ${ }^{28}$ the district court concluded that a local prison was not complying with a broad $\operatorname{order}^{20}$ to eliminate the imposition of cruel and unusual punishment, and placed the prison under the direct scrutiny of the court by appointing a "federal monitor" to inspect prison records and observe the management and operation of the prison. ${ }^{30}$ In other cases involving similar problems, courts have required the defendants to file periodic reports on compliance. ${ }^{31}$

conditions in the Orleans Parish Prison violated the Constitution, the district court in Hamilton v. Schiro, 338 F. Supp. 1016 (E.D. La. 1970), found that conditions had not been corrected. The court appointed a special master and charged him with fashioning a plan for improving the prison. 1 PRISON L. REP. 185 (1971). See Hamilton v. Landricu, 351 F. Supp. 549 (E.D. La. 1972) (master's plan, which included such extensive reforms as the construction of a new hospital, the creation of psychiatric, dental, and drug abuse programs, and the upgrading of qualifications for all security personnel, accepted). In Mills v. Board of Educ., 348 F. Supp. 866 (D.D.C. 1972) (mentally impaired children have a right to a special public education), the court stated:

If any dispute should arise between the defendants which requires for its resolution

a degree of expertise in the field of education not possessed by the Court, the Court

will appoint a special master pursuant to the provisions of Rule 53 of the Federal

Rules of Civil Procedure to assist the Court in resolving the issuc.

Id. at 877. To date, no such appointment has been made.

28. 501 F.2d 1291, 1321 (5th Cir. 1974), aff'g 349 F. Supp. 881 (N.D. Miss. 1972) (discusses the appointment of the monitor). See 16 Crim. L. Rep. 2481 (1975) (later opinion).

29. The original order of the court prohibited the arbitrary and unjustified censorship of mail, required that the administrative discipline proceedings comport with duc process standards, proscribed corporal punishment, and cstablished standards for confinement in maximum security. $349 \mathrm{~F}$. Supp. at 893-905.

30. A monitor with similar powers was appointed in Waync County Jail Inmates v. Wayne County Bd. of Comm'rs, 1 l'Rison L. Rer. 186, 188 (Gir. Ct., Wayne Co., Mich., 1972). The monitor made frequent visits to the jail, investigated inmate complaints of noncompliance with the court order, and reported to the court on his findings. See generally Inmates of Attica Correctional Facility v. Rockefeller, 453 F.2d 12, 25 (2d Cir. 1971) (directing the district court to consider the appointment of monitors at Attica l'rison in New York); Stroman v. Griffin, 331 F. Supp. 226, 330 (S.D. Ga. 1971) (court did not ap. point a monitor, but the judge noted, "A few wecks ago I paid an unannounced visit to the jail."),

31. Wald \& Schwartz, Trying a Juvenile Right to Treatment Suil: Pointers and Pitfalls for Plainliffs, 12 AM. Crim. L. Rev. 125, 162 (1974). Such periodic reports were filed in Wyatt.

Laughlin MeDonald, Director of the Southern Regional Office of the ACLU Foundation, has stated that most of the prison descgregation decrees issued by southern federal courts are unimplemented, and that this could have been avoided if more courts had retained jurisdiction and required the defendants to submit periodic reports to the court. McDonald, Enforcing the Prison Desegregation Decree (unpublished paper delivered at All ACLU Lawyers' Conference, Mar. 24, 1973) (on file with Yale Laz Journal). Cf. Lec 
A third method of implementation has involved the judicial appointment of ombudsmen ${ }^{32}$ to hear inmate complaints and grievances, conduct investigations, and make recommendations to the court. Unlike masters and monitors, which are envisioned as temporary, interim measures to aid in the implementation of decrees until compliance is achieved, ombudsmen have sometimes been included as part of the substantive relief, i.e., part of the restructuring of the institution. ${ }^{33}$ For example, in Morales 0 . Turman, ${ }^{34}$ the court appointed an ombuds-

v. Washington, 263 F. Supp. 327, 333 (M.D. Ala. 1966) (per Johnson, J.), aff'd per curiam, 390 U.S. 333 (1968) (elaborate reporting requirements).

Patricia M. Wald, attorney for plaintiffs in Mills v. Board of liduc., 348 F. Supp. 866 (D.D.C. 1972) (right of mentally impaired children in Washington, D.C., to be provided special public education), has noted that the failure of the court decree to require periodic reports has hindered implementation and impaired the ability of the attorncys for the plaintiffs and amici to protect their clients' rights:

The Mills decree makes no provision for periodic reporting on implementation to either the court, plaintiffs' attorneys, or the public, once the defendants' plan and the September interim report were made. As a result, the plaintiffs' attorneys, though they are legally entitled and ethically compelled to institute contempt or enforcement proceedings, if they think the decree is not being enforced, must depend on random complaints or their own investigative efforts to find out what is going on. Practically, this is difficult for busy practicing attorneys to do in a system with 200 separate schools and a possible 14,000 students who may be in their orbit of interest. Similarly, school administrators may be too busy or too harassed to compilc information they don't legally have to, or they may not seck gratuitously to supply their potential adversaries with full details on internal mistakes or problems.

Wald, Implementing Mills: The First Six Months, at 12-13, Mar. 1973 (unpublished paper, on file with Yale I.aw Journal) (footnote omitted).

32. The ombudsman is a government official who hears and investigates complaints by private citizens against government agencies and officials. The concept originated in Scandinavia, where the ombudsman is a commissioner appointed by the national legislature. In the traditional model, an ombudsman (1) is independent of the agency or organization which he investigates, (2) has full powers of investigation, including access to all official files and to all personnel, and (3) makes recommendations for changes, but has limited or no power to order that the recommendations be implemented. Acceptance of the ombudsman's recommendations depends on the respect for his office and on his ability to publicize the recommendations. See generally Gellhorn, The Swedish Justitieombudsman, 75 YALE L.J. I (1965). For a discussion of the role that ombudsmen in Scandinavia have played in the mental health field, see Broderick, Justice in the Books or Justice in Action-An Institutional Approach to Involuntary Hospitalization for Mental Illness, 20 CATH. U.L. REv. 547, 637-44 (1971). See generally Broderick, One-Legged Ombudsman in a Mental Hospital: An Oner-the-Shoulder Glance at an Experimental Project, 22 CaTH. U.L. Rev. 517 (1973).

In New York, ombudsmen have been appointed by executive decision to avoid abuses in the juvenile justice system. The program was established in 1971 by the New York State Division for Youth (DFY) to provide their own administrators with independent reports on conditions in the state training schools, and to cstablish a mechanism for handling youths' complaints. Nejelski \& LaPook, Monitoring the Juvenile Justice System? How' Cait You Tell Where You're Going, If You Don't Know W'here You Are?, 12 .M. CriM. L. Rev. 9, 29 (1974); Comment, The Penal Ombudsman: A Step Toward Penal Reform, 3 PAC. L.J. 166 (1972). However, the DFY ombudsman does not fit the traditional model in that he is neither independent of the agency nor able to publicize his recommendations as a method of bringing about their implementation.

33. See Martarella v. Kelley, 359 F. Supp. 478 (S.D.N.Y. 1973) (provision for a permanent ombudsman as part of a restructuring of a youth prison agreed upon by the plaintiffs and defendants but not coupled with a retention of jurisdiction by the court).

34. 364 F. Supp. 166 (E.D. Tex. 1973), 383 F. Supp. 53 (E.D. Tex. 1974) (the ombudsman appointed was a relatively low-ranking employee of the Texas Youth Council (TYC), which ran the juvenile institutions that were the subject of the litigation). 
man during the pendency of the litigation to hear grievances of youths confined in state juvenile institutions, to report to the court on violations of the court's order, and to make recommendations to the defendant state officials. ${ }^{35}$ The final order in Morales proposed to make the appointment permanent. ${ }^{36}$

Courts have thus developed several innovative and flexible techniques for implementing judicial orders. Before examining the implementation process in the Wyatt case, it is necessary first to explore briefly the course of litigation and the final decree that emerged.

\section{The Decree in Wyatt}

The facts which gave rise to the Wyatt litigation were quite different from those which underlay the decree. Wyatt originated as a labor dispute. Cuts in the Alabama cigarette tax forced the Mental Health Commissioner, Dr. Stonewall B. Stickney, to order the firing of 99 employees of Bryce Hospital, an institution for the mentally ill in Tuscaloosa, Ala. ${ }^{37}$ On October 23, 1970,38 the patients at Bryce and the discharged employees filed suit to rescind the order, alleging that the terminations would deny the approximately 5000 patients any prospect of receiving adequate treatment. ${ }^{30}$ In chambers, Judge Johnson stated that the employees could probably obtain adequate relief in state court, but added that he was concerned about the plight of the patients within the institution for whom, without the care of these professionals, adequate treatment would not be available. ${ }^{40}$

Largely in response to Judge Johnson's expressed concern, the plaintiffs shifted the focus of the litigation to the adequacy of care within Bryce Hospital. ${ }^{11}$ On January 4, 1971, the plaintiffs amended the original complaint to request "that this court declare that patients confined to any state-operated mental health facility are constitution-

35. 364 F. Supp. 166. The ombudsman was permitted to attend all staff meetings which discussed policy and procedures, and was given access to all records of the institution.

36. 383 F. Supp. 53, 120-21 (E.D. Tex. 197t). Although the court called the permanent post a "monitor," the description more closely fits the term "ombudsman" that was used originally; some confusion in terminology should be expected when new mechanisms are fashioned.

37. Sce p. 1349 infra.

38. Complaint at 1 (Oct. 23, 1970) (on file with Yale Law Journal). The defendants included Stickney, the members of the Alabama Mental Health Board, and then Gov. Albert P. Brewer.

39. Id. at 6.

40. Drake Interview, supra note 6. Sec Drake, supra note 5, at 596 n.27.

41. Drake Interview, supra note 6 . The Fifth Circuit stated that the reason for the shift in the suit's focus was "not entircly clear from the record before us." $503 \mathrm{~F} .2 \mathrm{~d}$ at 1308. 
ally entitled to adequate, competent treatment," and that "defendants be enjoined from operating Bryce Hospital in a manner that does not conform to constitutional standards of delivering adequate mental treatment to its patients." 42 With the issue thus more clearly focused, the Wyatt litigation proceeded through a series of stages. At each stage the court apparently sought to encourage voluntary compliance by the defendants while making clear that it would assume a more active role if necessary.

The first stage of the litigation centered on the right to treatment $t^{43}$ and on the factual circumstances of the patients at Bryce. The court held that this right existed, emanating from the due process clause. ${ }^{44}$

To deprive any citizen of his or her liberty upon the altruistic theory that the confinement is for humane therapeutic reasons and then fail to provide adequate treatment violates the very fundamentals of due process. ${ }^{4 \overline{5}}$

The court found that the conditions and treatment methods within the institution were "scientifically and medically inadequate" and "failed to conform to any known minimums established for providing treatment for the mentally ill." $\neq 0$ Defendants were given ninety days to develop and file with the court a plan for the provision of adequate treatment at Bryce. ${ }^{47}$ The court invited the Department of Justice to enter the case as amicus curiae ${ }^{ \pm 8}$ and granted the request of several national mental health and civil liberties organizations to participate as amici. ${ }^{49}$

42. Motion-styled "Amendment"-for Leave to Amend Complaint (Jan. 4, 1971) (on file with Yale Law Journal).

43. In recent years, many lower federal and state courts have held that persons involuntarily confined without a criminal conviction have a constitutional right to receive treatment. See cases cited in Developments-Civil Commitment, supra note 5, at 1316.18 nn.2, 4 .

44. 325 F. Supp. at 785. See generally Jackson v. Indiana, 406 U.S. 715, 738 (1972) ("due process requires that the nature and duration of commitment bear some reasonable relation to the purpose for which the individual is committed").

45. $325 \mathrm{~F}$. Supp. at 785. The court stated that the right to treatment is a present right to which the plaintiffs have an immediate claim, and that "the failure to provide suitable and adequate treatment to the mentally ill cannot be justified by lack of staff or facilities." Id. at 784 .

46. Id.

47. Id. at $785-86$.

48. Id. at 786 .

49. Order (Aug. 20, 1971). The organizations included the American Psychological Association, the American Orthopsychiatric Association, the American Civil Liberties Union and the American Association on Mental Deficiency. The National Association for Mental Health and the National Association for Retarded Citizens joined as amici for the appeal. All amici were allowed full participation rights, including the right to present evidence and cross-examine witnesses. Halpern Interview, supra note 6. All amici, with the exception/of the United States, were represented by the Center for Law and
Social Policy, Washington, D.C. 
During the next stage of the litigation the court granted plaintiffs' amendment to enlarge the class to include patients involuntarily committed to all three Alabama mental hospitals-Bryce, Partlow State School and Hospital (for the mentally retarded), in Tuscaloosa, and Searcy Hospital (for the mentally ill), in Mount Vernon.50 In December 1971, the court recognized three requisites for effective treatment: “(1) a humane psychological and physical environment, (2) qualified staff in numbers sufficient to administer adequate treatment and (3) individualized treatment plans." $\mathrm{It} \mathrm{found} \mathrm{the} \mathrm{defendants} \mathrm{had}$ failed to meet these requisites, ${ }^{52}$ and therefore set the case for a hearing at which the parties and amici were to present evidence on conditions in the institutions and to propose detailed minimum standards which would comply with the three general requisites of effective treatment. ${ }^{.53}$ Decision was deferred on the amici's request to appoint a panel of masters to take over the operation of the institutions. ${ }^{54}$

At the hearings ${ }^{5 \overline{5}}$ on conditions in the institutions, the evidence established specific deficiences in treatment at Alabama's state mental hospitals. ${ }^{50}$ At the close of the hearings the court, impressed by the

\footnotetext{
50. 334 F. Supp. at 1342 n.l (1971).

51. Id. at 1343 .

52. Id. The court's finding that defendants had failed to meet the minimum conditions of treatment was based on a report filed by defendants that stated their recent efforts to improve the institutions and the plans for continued improvements, Report of Alabama Department of Mental Health (Sept. 23, 1971), to which plaintiffs and amici filed detailed objections. P'laintiff' Objections to Defendants' Report (Oct. 13, 1971); Response of U.S. to Defendants' Report (Nov. 15, 1971). The facts supporting these findings were summarized by the court:
}

[T]he dormitories are barn-like structures with no privacy for the patients.... The

toilets in restrooms seldom ... have partitions between them. These are dehumanizing

factors which degenerate the patient's self-esteem ... contributing to the poor psy-

chological environment are the shoddy wearing apparel furnished the patients, the

nontherapeutic work assigned... and the degrading and humiliating admissions

procedures which creates in the patient an impression of the hospital as a prison or as a "crazy house."

334 F. Supp. at 1343.

53. 334 F. Supp. at 1344; 344 F. Supp. at 375; 344 F. Supp. at 390 .

54. 334 F. Supp. at 1344 .

55. Upon motion of the defendants, separate hearings were held on treatment for the mentally retarded at Partlow and for the mentally ill at Bryce and Searcy. Defendants' Motion (Jan. 4, 1972).

56. See Brief of Amici Curiac American Ass'n on Mental Deficiency, American Civil Libertics Union, American Orthopsychiatric Ass'n, American Psychological Ass'n, National Ass'n for Mental Health, and National Ass'n for Retarded Children at 5 (Nov. 7, 1972), 503 F.2d 1305 (5th Gir. 1974) (on file with Yale Law Journal) [hereinafter cited as Amici's Appeal Bricf]. The evidence showed a lack of individualized treatment plans and programs, id. at 29; a lack of privacy, id. at 20; unsafe and unsanitary conditions, id. at 21-22; malnutrition, $i d$. at 22-23; inadequate staff, $i d$. at 25-28; and inappropriatc staff attitudes, id. The expert testimony often revealed shocking conditions. For example,

Testimony established that four residents died duc to understaffing, lack of supervision, and brutality. One had a garden hose inserted in his rectum for five minutes by a working inmate who was cleaning him; one died when a fellow inmate hosed him with scalding water; another died when soapy water was forced into his mouth; 
urgency of the situation, issued an Interim Emergency Order "to protect the lives and well-being of the residents of Partlow."st

In the last stage of the litigation, the court issued two final "Orders and Decrees" covering the three institutions.38 Relying upon stipulations entered into by the parties and amici and drawing upon the largely uncontested evidence of the hearings, ${ }^{, 9}$ the court promulgated a comprehensive list of standards held to be the constitutional requirements of adequate treatment. ${ }^{00}$

and the last died by a self-administered overdose of drugs which had been inadequately secured.

Id. at 25. An expert witness testified that:

I found one girl... squatting on the floor in a sort of wooden cage-lihe contrivance.... I was told that she spent her waking hours in this wooden cagc.... I asked what happened when she is released from this thing, and I was told that she would then scoot along the floor. I was also told that she could stand....

I asked the attendant what happened if this girl was given a walker, and I was told this had never been done; it had never been tried. I noticed one of the other young girls who was tied in bed by a waist restraint jumped out of bed and ... was promptly put back in.... I was told that the doctors had mandated she be ticd in bed, because when she assumed an upright position, she tended to vomit.

Testimony of Dr. Philip Roos, at 16 (Feb. 29, 1972) (on file with Yalc Law Journal)

[hereinafter cited as Roos Testimony] (describing l'artlow State School and Hospital).

The food was slopped out uncercmoniously by the working residents. There was a kind of a cake... as part of the meal, and it was handed out by the working residents using their hands and dropping it on the trays. There were no knives or forks. Many of the residents ate with their hands....

Id. at 12. One witness summarized "life" at Partlow as follows:

I think if you walk through Partlow, you can sec... the effect-the people who begin to become involved in eccentric mannerisms, the rocking back and forth, peculiar behavior mechanisms, the people who sit in a semi-stupor in a place, without any activity, the people who slowly deteriorate and turn to the simple elements of human behavior.... We have ample documentation in this country that individuals who come to institutions and can walk stop walking, who come to institutions and can talk will stop talking, who come to institutions and can feed themselves will stop feeding themselves; in olher words, in many other ways, a steady process of deterioration.

Amici's Appcal Brief at 33 (emphasis in Brief).

57. Interim Emergency Order (Mar. 2, 1972) (on file with Yale Law Journal).

58. 344 F. Supp. 373 (M.D. Ala. 1972); 344 F. Supp. 387 (M.D. Ala. 1972).

59. See Memorandum of Agreement of Plaintiffs, Defendants, and Amici Curiae American Orthopsychiatric Ass'n, American Psychological Ass'n, American Civil Liberties Union, and American Ass'n on Mental Deficiency, at 1 (Feb. 27, 1972) (on file with Yale Law Journal); Amici's Appeal Brief, supra note 56, at 10 n.5. These stipulated standards included the following: (1) $A$ patient's sense of his or her own dignity and privacy is a prerequisite for effective treatment, $i d$. at 20 ; (2) mental institutions should not be maintained on the uncompensated, nontherapeutic labor of the inmates, id. at 23; (3) the overuse of restraints and isolation is an unacceptable substitute for active treatment programs, id.; (4) every institution should provide for the safety of its residents, id. at 21; and $(5)$ staff-patient ratios must be maintained at a level commensurate with the necds of the patient population, id. at 25-28. The mental health associations noted that:

[A]ll 49 of the standards relating to Partlow State School and Hospital-with the exception of the standards relating to seclusion, temperature, Human Rights Committee and proper care of patients' physical conditions, such as tuberculosis-were agreed upon and stipulated to by the parties.

Id. at 10 n.6. This agreement greatly simplified the district court's task at this intermediate stage of the litigation, because it made it unnecessary to use adversary hearings to develop the complicated treatment standards.

60 . The standards for Partlow provided that the residents have a right to: adequate habilitation, 344 F. Supp. at 396; individualized habilitation plans, id. at 397; a humane 
Most significantly for the implementation of the decree examined in this Note, the court appointed a seven member Human Rights Committee $^{b 1}$ for each institution to oversee defendants' progress in complying with the designated standards. ${ }^{62}$ The purpose and function of these committees was defined as follows:

... [T] $]$ hese committees ... shall have review of all research proposals and all rehabilitation programs, to ensure that the dignity and the human rights of patients are preserved. The committees also shall advise and assist patients who allege that their legal rights have been infringed or that the Mental Health Board has failed to comply with judicially ordered guidelines. At their discretion, the committees may consult appropriate, independent specialists who shall be compensated by the defendant Board. ${ }^{63}$

In a footnote, the court supplemented the scope of each Human Rights Committee's function:

The recitation of the licenses of this committee... is not intended to be inclusive. The Human Rights Committee of each mental health institution shall be authorized, within the limits of reasonableness, to pursue whatever action is necessary to accomplish its function. ${ }^{64}$

The court enjoined the defendants "from failing to implement fully and with dispatch each of the standards," 65 and further noted:

The massive program of reform and reorganization to be launched at Partlow requires the guidance of a professionally qualified and experienced administrator. Consequently, this Court will order that defendants employ such an individual on a permanent basis. Should defendants fail to do so, or otherwise fail to comply timely with the provisions of this decree, the Court will be obligated to appoint a master. ${ }^{\circ 6}$

\footnotetext{
physical and psychological environment, including the right to dignity, privacy, and humane care, id. at 399-405; and sufficient qualified staff to provide care, id. at 405 . Habilitation was defined by the court as "the process by which the staff of the institution assists the resident to acquire and maintain those life skills which enable him to cope more effectively with the demands of his own person and of his environment and to raise the level of his physical, mental, and social efficiency ...." Id. at 395. The standards were somewhat different for the two hospitals for the mentally ill-Bryce and Searcy. See 344 F. Supp. at 379 .

61. Id. at 378,392 .

62. Id.

63. 344 F. Supp. at 376 .

61. 344 F. Supp. at 392 n.10.

65. Id. at 394 .

66. $7 d$.
} 
The court stated that lack of funds was a "legally insufficient reason" 07 for failing to meet Alabama's constitutional obligations.

In May 1972, Governor Wallace and the Alabama Mental Health Board filed separate notices of appeal to the Fifth Circuit. ${ }^{68}$ More than two years later, on November 8, 1974, the Fifth Circuit issued its opinion affirming the district court. ${ }^{69}$

\section{Implementation of the Wyatt Decree}

Before discussing in detail the problems that occurred in implementation and the roles played by the court, the parties, the amici, and the Human Rights Committees, it is necessary to provide an overview of the implementation process during the two years between the issuance of the decree and the affirmance by the Fifth Circuit. This examination focuses primarily on one of the three institutions covered by the decree: Partlow State School and Hospital (Partlow). The overview presents the interactions of the parties, the problems and changes occurring within the institution, and the significant legal actions. It is followed by a section which examines the actual functioning of the Partlow Human Rights Committee, the plaintiffs and amici, and the defendants, evaluating how they handled their responsibilities and utilized their powers. A final section addresses the general problems of implementing the Wyatt decree.

\section{A. An Overview of Implementation}

The task of implementation began several months before the final decree with the court's Interim Emergency Order of March 2, 1972, ${ }^{\prime \prime}$ which required the elimination of all hazardous and unsanitary conditions at Partlow, ${ }^{71}$ the hiring of 300 additional staff members, ${ }^{72}$ and a reduction of the institution's population. ${ }^{73}$ The Interim Order produced some improvements in the institution, including a substantial

67. Id. (footnote omitted). The court reserved ruling on plaintiff's motion that the Mental Health Board be directed to sell its extensive land holdings in order to provide the funds required for the improvements. Id. at 393. The court also reserved ruling on plaintiff's motion to enjoin the state from spending moncy for nonessential functions until the necessary funds were available to meet the financial needs of the Mental Health Board. Id.

68. Notice of Appeal of the Alabama Mental Health Board (May 12, 1972); Notice of Appeal of Gov. George C. Wallace (May 12, 1972).

69. 503 F.2d 1305 (5th Cir. 1974).

70. Interim Emergency Order (Mar. 2, 1972) (on file with Yale Law Journal).

71. Id. at 2.

72. Id.

73. Id. at 3. 
upgrading of sanitary conditions and a reduction in the population of Partlow's wards which partially alleviated hazardous overcrowding. ${ }^{\text {it }}$ However, the Order also caused substantial disruption in the state executive branch ${ }^{75}$ and in the institution..$^{70}$ For example, the massive hiring of new resident care workers, dictated by the Interim Emergency Order, caused considerable confusion and inefficiency as experienced staff members had to take time to train the new employees. ${ }^{i 7}$

It was against this background that the final decree was issued on April 13, 1972, and the Human Rights Committees (HRC's) were appointed. ${ }^{78}$ While the powers of the HRC's were not clearly delineated, their responsibilities were. Judge Johnson instructed the HRC's to establish "free and easy communication" between themselves and the residents, the staff, and the administration; to meet frequently with the administration; to inspect the institution periodically; to determine whether the court orders were being effectively implemented; and to make reports to the court. ${ }^{70}$ The court also instructed the administration of the institutions that the HRC's were to be permitted full access

74. P. Roos, Progress Evaluation Report on the Partlow State School in Tuscaloosa, Ala. at 12 (Oct. 9, 1972) (on file with Yale Lau Joumal) [hereinafter cited as Roos Progress Report].

75. Stickney, the Commissioner of the Alabama Board of Mental Health, was discharged from his position. Among the reasons for his discharge was a disagreement with the Governor over whether the state was bound to pay for improvements in the three institutions that had been agreed to in stipulations before the court. Stickney, Problems in Implementing the Right To Treatment in Alabama: The Wyatt \%. Stickney Case, 25 Hosp. AND Community l'sychiatry 456, 457 [hereinafter cited as Stickncy Article]; Stickney Interview, supra note 6. James C. Folsom, Superintendent of Bryce Hospital, was also discharged from his position. Associate Commissioner of Mental Health, Charles L. Aderholt, was appointed by the Governor to replace Stickney as Commissioner. Stickney Interview. However, Aderholt was forced to resign after one year. Stickney Interview; Drake Interview; DeMent Interview. He was replaced by General Taylor Hardin who had recently been forced to resign his longheld post as State Finance Commissioner because of an alleged conflict of interest between that position and his membership in the Alabama National Guard. Stickney Article, supra; Stickney Interview; Drake Interview; Buckley Interview. Many persons interviewed expressed the view that as Finance Commissioner, Hardin had close political ties to Gov. Wallace and that his appointment as Commissioner of Mental Health greatly diminished the independence of the Mental Health Board. Stickney Interview; Martin Interview.

76. Partlow's Acting Superintendent at the time of the litigation, Peter Blouke, was discharged almost immediately after the issuance of the decree for having coopcrated with the plaintiffs' lawyers during the litigation. Blouke Interview, supra note 6; Baumeister Interview; Fowler Interview. Blouke was replaced by Dr. John Hottel, who resigned after expressing frustration about dealing with the Partlow Human Rights Committe which he unsuccessfully sought to have the court disband. Tillman Interview; Buckley Interview; Stickney Interview. See p. 1356 infra. Hottel was replaced as superintendent by Richard E. Buckley, who was discharged shortly after the case was affirmed on appeal. N.Y. Times, Mar. 31, 1975, at 11, col. I.

77. Stickney Interview, supra note 6; Blouke Interview.

78. 344 F. Supp. at 378,344 F. Supp, at 392.

79. Letter from Judge Johnson to Dr. E.L. McCafferty, Jr., Chairman of the Searcy HRC, Aug. 8, 1972 (on file with Yale Law Journal) [hercinafter cited as McCafferty Letter]. Judge Johnson sent copies of this letter to the Partlow and Bryce Human Rights Committees. 
to the institution, staff, patients, and records, and that no reprisals were to be taken against staff members for reporting to the HRC's. ${ }^{\mathrm{No}}$ Finally, the court stressed that implementation was the task of the defendants, not of the HRC's. ${ }^{81}$

The Partlow Human Rights Committee (PHRC) quickly assumed an aggressive stance. ${ }^{82}$ The committee divided the responsibility among its members for investigating and reporting the progress of implementation in various areas, ${ }^{83}$ and held bi-weekly meetings to discuss findings and confer with the Partlow staff and administrators. ${ }^{84}$

The defendants, particularly the institution's administration, resented the PHRC because they felt that its activities exceeded the scope of the decree. ${ }^{85}$ Moreover, there was a considerable turnover of personnel at Partlow. ${ }^{86}$ Staff members, many of whom had been stung by critical press coverage of the institution during the litigation, were often frustrated by the requirements placed upon them by the decree. ${ }^{87}$ Some complained that residents became more "unruly" as they learned of the decree, copies of which were available to the residents. ${ }^{88}$ However, even though the administration resented the intrusion of the PHRC and the staff complained about the decree's requirements, the patient population continued to decrease through discharges and transfers, ${ }^{89}$ and steps were taken to upgrade living conditions in the institution. ${ }^{90}$

On the basis of its own investigations, the PHRC contested several of the administration's claims of progress within the institution. ${ }^{01}$ For

80. Id. at 1-2.

81. Id. at 3 .

82. Tillman Interview, supra note 6; Keever Interview; Stickney Interview; Buckley Intervicw.

83. PHRC Report (Sept. 24, 1972).

84. Stickney Interview, supra note 6; Bucklcy Interview.

85. Id.

86. Id.

87. Buckley Interview, supra note 6.

88. Tillman Interview, supra note 6; Wagnon Interview: See 344 F. Supp. at 406 (standard 42).

89. During the first year of implementation, the resident population at Partlow decreased substantially, due to discharges purportedly based on the diagnoses and evaluations which determined whether confinement in Partlow was appropriate. See note 133 infra.

90. For example, telephones were installed. Defendants' Report to the Court Concerning Partlow State School and Hospital at 86 (Oct. 10, 1972) (on file with Yale Law Journal). Mail censorship was discontinued. Id. at 89 . The wards were painted. Tillman Interview, supra note 6 . Toilet facilities were partitioned to provide residents with greater privacy. Id. Additional staff members were hired to diagnose and cvaluate residents to determine appropriate placement and treatment. Roos Progress Report, supra note 74 , at 12,16 .

91. In addition to members' own investigations, the PHRC hired a professional consultant to conduct investigations and to advise it of the most serious problems remaining in the institution. Roos l'rogress Report, supra note $\mathbf{7 4}$, at 12, 16. For cxample, the con- 
example, the PHRC feared that many of the discharges designed to relieve overcrowding were inappropriate and detrimental to some of the patients released. ${ }^{22}$ Eventually, it accused the administration of "dumping"'s patients to get them beyond the committee's authority. ${ }^{94}$ The PHRC informally contacted Judge Johnson for instructions on whether the scope of its authority included discharged patients. ${ }^{95}$ The Judge advised the committee members to confine their attention to patients within Partlow's walls. ${ }^{98}$ Information gathered by the PHRC also led the attorneys for the plaintiff patients to charge that the administration had violated the court's decree by failing to compensate the patients for performing maintenance work at the institution. ${ }^{97}$ The

sultant's report noted that residents were still being confined in small, closet-like "seclusion rooms," id. at 20, a practice which had been prohibited in the decree and which the administration claimed had been eliminated. Defendants' Report to the Court Concerning Partlow State School and Hospital at 100 (Oct. 10, 1972) (on file with Yale Law Journal).

92. PHRC Report (June 9, 1972).

93. Id. "Dumping" can be defined as rapidly discharging residents without services which would enable them successfully to reenter and remain within the community. A consultant's letter cautioned Judge Johnson against the dangers of "dumping" patients for the purpose of reducing overcrowding: "A well planned skillfully implemented delicate balance must be maintained between decreasing the size of institutional populations and development of community resources." Letter from James D. Clements, M.D., Director of the Georgia Retardation Center, Atlanta, Ga., to Judge Johnson at 2, June 11, 1973 (on file with Yale Law Journal).

94. Tillman Interview, supra note 6 .

95. Id.; Wagnon Interview, Public concern was aroused when several persons who were discharged engaged in anti-social conduct. For example, several dischargees were arrested for indecent exposure and child molestation. PHRC Report (Apr. 16, 1973). See p. 1374 infra.

96. These instructions created many problems for the PHRC because it was unclear whether they only advised the committee on its prioritics or whether they prohibited the committee from operating outside the institution. The confusion was exacerbated because some residents who were "transferred" remained on Partlow's rolls. In fact, the concept of "Partlow's walls" became fairly nebulous in light of the increasing number of residents participating in deinstitutionalization programs who were allowed out of the institution for graduated intervals, and the number of residents who cither ran away or wandered off and got lost. Many committee members felt frustrated by the court's restriction of their jurisdiction. These members felt that without the simultaneous development of community scrvices, the deinstitutionalization philosophy which they saw in the court's decree and which had originally attracted their interest, would be defeated. Dinsmorc Interview, supra note 6; Keever Interview; Murphy Interview; Pernell Interview; Wagnon Interview. See note 221 infra.

97. Motion for Spccific Enforcement of Prior Orders, or in the alternative or conjunctive, Motion to Show Cause Why Defendants Should Not Be Held in Contempt (July 5, 1972) (on file with Yale Law Journal). Plaintiffs alleged that the defendants had failed to comply with the Fair Labor Standards Act $\$ 6,29$ U.S.C. \$ 206 (1966), which was incorporated in standard 33 of the Partlow decree, 344 F. Supp. at 402-03, and in standard 18 of the Bryce and Searcy decree. 344 F. Supp. at 381 . Plaintiffs requested back pay and attorneys' fees, in addition to enforcement of the standard. The defendants responded that they had received approval from the Department of Labor to establish work programs and that all payments to patients were made in strict compliance with 29 C.F.R. $\$ \S$ 524, 525, which permit certified disabled persons to be paid at a percentage of the minimum wage based on their levels of productivity. Response of Defendants to Plaintiffs' Motion for Specific Enforcement of July 5, 1972 (Aug. 23, 1972) (on file with Yale Law Journal). 
court amended the decree to allow therapeutic labor without compensation. ${ }^{98}$

Relations between the PHRG and the administration became very strained during this period..$^{90}$ As a result, the defendants informally requested the court to dissolve the PHRC, alleging that the committee was obstructing implementation. ${ }^{100}$ When this request was denied, the defendants moved to obtain a clearer delineation of the powers of the PHRC, ${ }^{101}$ but this motion was later withdrawn after negotiations between the parties. ${ }^{10: 2}$ The administration also refused to cooperate with the PHRC's attempts to investigate reports of resident abuse. ${ }^{103}$ When the amount of information that the PHRG could obtain was thus substantially reduced, the committee requested the assistance of the local United States Attorney, who had been designated by the court as the committee's counsel. ${ }^{104} \mathrm{He}$, in turn, enlisted the aid of the Federal Bureau of Investigation (FBI) to investigate the allegations. ${ }^{105}$

By the end of the first year after the final decree, relations between the administration and the PHRC had stabilized somewhat. The administration had accommodated itself to the occasional presence of the PHRC; there were no longer acrimonious conflicts over patient supervision and safety or over sanitation in the institution. The administration took the first steps toward meeting the standards set forth in the decree, primarily the formulation of a comprehensive habilitation plan for each individual resident. ${ }^{106}$ However, progress was very slow in actually carrying out these plans, and few were fully imblemented. ${ }^{107}$ Notwithstanding these improvements, new issues of disagreement con-

98. Order (Dec. 4, 1972) (on file with Yale Law Journal). According to the plaintiffs' lawyers and the present counsel for the Mental Health Board, the manner in which Judge Johnson handled this proceeding demonstrated that the court would not welcome further motions to show cause. Dean Interview, supra note 6; Drake Interview; Humphrics Interview.

99. This tension was accompanied by a good deal of backbiting. For example, Dr. Stickney characterized the PHRC members as "pharisces" who "believe their own propaganda," Stickney Interview, supra. note 6, and one former PHRC member recalled that "we were heartily despised by the institution." Keever Interview.

100. Drake Interview, supra note 6; Stickney Interview; Tillman Intervicw.

101. Motion for Order of Modification (July 19, 1972) (on file with Yale Law Journal).

102. Dismissal of Defendants' Motion for Order of Modification and Plaintiffs' and Defendants' Joint Motion for Order of Modification (Aug. 4, 1972) (on file with Yale Law Journal).

103. Tillman Interview, supra note 6.

104. Letter from Judge Johnson to Ira DeMent, U.S. Attorney, July 20, 1972 (on filc with Yale Law Journal). See note 172 infra.

105. PHRC Report (Dec. 11, 1972); DeMent Interview, supra note 6.

106. The formulation of these habilitation plans meant that every resident had been examined, diagnosed, and prescribed a treatment plan which, if implemented, would provide self-proficiency training to enable the resident to reenter the community. Buckley Interview, supra note 6 .

107. Buckley Interview, supra note 6; Internal Memorandum to Charles R. Halpern, Center for Law and Social Policy, June 17, 1973 (on filc with Yale Law Journal). 
tinued to arise between the PHRC and the administration. The committee found that several Partlow residents had been sterilized, which it believed was in violation of a standard in the decree banning "unusual or hazardous treatment" without the prior review and consent of the PHRC and of the resident or designated guardian. ${ }^{108}$ On the basis of the PHRC's findings, the plaintiff patients submitted a motion to Judge Johnson for further relief. ${ }^{109}$ A three-judge court was convened and struck down Alabama's sterilization law.110 Thereafter, Judge Johnson amended the decree to include due process standards for the sterilization of residents. ${ }^{111}$

Grounds for further conflict were contained in the first annual reports, submitted to the court in 1973,112 in which the defendants and the PHRC each evaluated compliance with the standards of the decree. The reports showed considerable disagreement as to the levels of compliance then achieved, because the defendants and the PHRC evaluated compliance by different methods. The PHRC measured compliance separately for each standard in the decree, and noted whether the institution was in complete compliance, partial compliance, or "no compliance," i.e., had failed to take any steps since the issuance of the decree. ${ }^{113}$ The PHRC did not consider restraints on the administra-

108. Standard 30,344 F. Supp. at 402 .

109. Amended Complaint or alternatively Motion for Further Relief (July 24, 1973) (on file with Yale Law Journal). Plaintiffs argued that AlA. Cone tit. 40, $\$ 243$ (1958) was unconstitutional on its face because it permitted the superintendent to prescribe and authorize the sterilization of any resident without standards or guidelines, irrespective of whether or not the superintendent was a physician, in violation of the due process and equal protection clauses of the Fourteenth Amendment and the prohibition against "cruel and unusual punishment" contained in the Eighth and Fourteenth Amendments. Amended Complaint, supra. The following allegation was offered to illustrate the statute's potential for abuse: "[A] physician... hired by the Defendants... suggested to the Superintendent and others that patients not be sterilized by tubal ligation but that numbers of patients could be lined up against a wall and zapped with cobalt radiation first in one ovary and then the other." Id. at 3 .

110. Wyatt v. Aderholt, Civil No. 3195-N(B) (M.D. Ala. Dec. 20, 1973) (on file with Yale Law Journal).

111. The court-ordered standards, which were formulated by the Justice Department, can be summarized as follows: 1) sterilization must be in the best interest of the patient; 2) sterilization must be a contraceptive measure of last resort; 3) all sterilizations arc banned for persons under 21 years of age; 4) sterilizees must be capable of giving, and must in fact give, their informed consent, except that surrogate consent will be permitted where the patient is incapable of giving such informed consent if that surrogate's consent is reviewed and approved by a Review Committee and a court of competent jurisdiction; 5) records shall be maintained of all Revicw Committee decisions and the reasons therefor. United States' Proposed Standards for Stcrilization of Mentally Retarded Residents of State Retardation Facilities 1-2, 5 (Oct. 29, 1973), Wyatt v. Aderholt, Civil No. 3195-N(B) (M.D. Ala. Dec. 20, 1973) (on file with Yale Law Journal).

112. Progress Report of the Partlow State School and Hospital (June 1, 1973) (on file with Yale Law Journal); Report of the Human Rights Committee for lartlow State School and Hospital (Apr. 2, 1973) (on file with Yale Law Journal).

113. Report of the Human Rights Committee for Partlow State School and Hospital (Apr. 2, 1973) (on filc with Yale Law Journal). 
tion, such as lack of funds, in judging whether the institution was in compliance. ${ }^{114}$ The defendants also considered each standard separately but their method of evaluation emphasized existing constraints. They regarded the institution as being in compliance if it had met the standard to the extent possible at that time. ${ }^{115}$ The administration viewed the PHRC's evaluations and recommendations as unrealistic and as interfering with its authority. ${ }^{116}$ An example of this conflict was a PHRC recommendation that the Partlow mental institution terminate the operation of its medical hospital and instead contract for medical services with the local municipal hospital. ${ }^{117}$ The Superintendent of Partlow informed the PHRC that he regarded such policymaking as an encroachment on his authority, but the PHRC was generally undaunted by administration criticism. ${ }^{118}$

Throughout the first year and a half, the court avoided involvement in specific disputes between the PHRG and the administration. For example, the PHRC sent, a letter to Judge Johnson requesting permission to hire a paid staff of resident advocates to better enable the committee to protect the rights of the patients within the institution. ${ }^{119}$ The Superintendent of Partlow opposed the proposal on the ground that the staff adequately represented the patients' interests. ${ }^{120}$ The Judge deferred decision on the committee's request, stating that he would not "take any action on this proposal until appellate review of this Court's decision in this case has been completed."121

Issues concerning the situation within the institution remained matters of dispute between the PHRC and the administration. ${ }^{22}$ The

114. Tillman Interview, supra note 6; Keever Interview; Buckley Interview.

115. Buckley Interview, supra note 6 .

116. Id.

117. PHRC Report (July 9, 1973) (on file with Yale Law Journal).

118. Id.

119. PHRC Report (Apr. 1, 1974) (on file with Yale Law Journal); A Proposal for Paid Staff Persons to be Assigned to Partlow State School and Hospital's Human Rights Committee (Apr. 15, 1974) (on file with Yale Law Journal).

120. PHRC Report (Apr. 1, 1974) (on file with Yale Law Journal); Buckley Interview; supra note 6.

121. Letter from Judge Johnson to Harriet Tillman, Apr. 18, 1974 (on file with Yale Law Journal). See note 221 infra.

122. For example, a dispute arose concerning the institution's policy of locking all doors between wards and buildings. The administration claimed that the locked doors were necessary to prevent theft, and to protect the safety of residents who lived on second- and third-floor wards enclosed by fire escapes. PHRC Report (Aug. 2, 1974) (on file with Yale Law Journal); Buckley Interview, supra note 6. The PHRC stated that the locked door policy created a fire hazard, was antithetical to principles of normalization enunciated in the decree, and was used only because of inadequate supervision. For a discussion of normalization principles, see testimony of Dr. Philip Roos, reported in 1 P.L.I., Legal Rights of THE Mentally Handicapped 487 (B. Ennis, P. Friedman \& B. Gitlin eds. 1973). The PHRC requested the administration to develop a plan for a security system which would permit rapid exit in the event of fire. PHRC Report (Aug. 
PHRC continued to submit its grievances and recommendations to the court. The court received most of these reports without comment, and did not use them as a basis for modifying or extending the decree. However, it responded to the June 1974 PHRC annual report, ${ }^{123}$ filed a year and a half after the final decree, with a sua sponte order directing the defendants to show cause why they were not in compliance with the committee's recommendations. ${ }^{124}$ The defendants responded to the order by stating that the institution either was in compliance or would be in the near future. ${ }^{125}$ Shortly thereafter, the Superintendent promulgated a directive to his staff requiring all meetings between Partlow personnel (and patients) and the PHRG to be cleared with his office, adding that he would prohibit any meeting which he deemed "unreasonable." 126 When the PHRC reported this to the court, ${ }^{127}$ the defendants filed a "Petition for Clarification"12s of the PHRC's responsibilities. The court ruled that the Superintendent's directive violated the court order by severely limiting the committee's access to the institution, and it therefore enjoined the Superintendent from interfering with the PHRC's activities. ${ }^{120}$

2, 1974). The administration maintained that this decision was within its discretion and not covered by the decree, and it therefore regarded the issue as beyond the authority of the PHRC. Id.; Buckley Interview, supra note 6. In contrast, Bryce Hospital instituted an "unlocked doors" policy in response to the decree's call for treatment in the least restrictive setting. After Bryce unlocked all doors between wards and buildings, some residents wandered away from the institution and caused a considerable disturbance in the community. A member of the Bryce HRC expressed the belief that the zeal with which Bryce's administration "over-complied" with the order was intended to provoke the community and embarrass the court. Wagnon Interview. See p. 1374 infra.

123. Third [Annual] Report to the United States Court by the Human Rights Committec for Partlow State School and Hospital (June 24, 1974) (on file with Yale Law Journal) [hereinafter cited as Third Annual Report].

124. Order to Show Cause (June 25, 1974) (on file with Yale Law Journal). The order did not direct the defendants to "show cause why they should not be held in contempt"; it instead directed them to show cause why they were not in compliance.

125. Defendants' Response to Order to Show Cause at 1-9 (July 24, 1974) (on filc with Yale Law Journal). Although they did not express it to the court, several of the defendants indicated discontent because they felt they were being held to show cause why they had failed to implement PHRC recommendations that were not required by the original decree. Buckley Interview, supra note 6; Humphries Interview. Among themselves, the defendants voiced their displeastre with the growing powers of the PHRC, which they thought allowed the committe to enforce its own priorities through the court in areas which should have been left to administrative discretion. Id.; Buckley Interview.

126. Standard Proccdurc Dircctive (Aug. 26, 1974) (concerning appearances of residents and staff before the HRC) (on file with Yale Law Journal). In an interview, Buckley cxplained that his directive was not aimed at severing communication between the institution and the PHRC; he stated that as long as he made himself available to the committee it had full access to the institution. Buckley Interview, supra note 6.

127. Letter from John Mathews to Judge Johnson, Aug. 30, 1974 (on file with Yale Law Journal); Report of Partlow Human Rights Committee (Aug. 31, 1974) (on file with Yale Law Journal).

128. Defendants' Petition for Clarification (Aug. 30, 1974) (on file with Yale Law Journal).

129. Order (Sept. 26, 1974) (on file with Yale Law Journal). 
Several weeks later, the Fifth Circuit affirmed the Wyatt case on appeal, ${ }^{130}$ and remanded it to the district court for a "determination of good faith efforts by state authorities to ensure [the constitutional right to treatment]."131 The first phase of implementation thus ended. ${ }^{132}$ It had resulted in substantial improvements within the institution, but there still remained a large disparity between the reforms achieved and the judicial mandate. ${ }^{133}$

\section{B. Problems Relating to the Partlow Human Rights Committee and the Parties During Implementation}

\section{The Partlow Human Rights Committee}

In appointing the Human Rights Committees, the court created an instrument intended to serve as its "eyes and ears" during the implementation process, to monitor the changes in the institutions and to ensure that the constitutional rights of the residents were not in-

130. 503 F.2d 1305 (5th Cir. 1974).

131. Id. at 1318.

132. This Note is limited to studying the implementation of the Wyatt decree during the pendency of the case on appeal. Because of Judge Johnson's uncertainty as to when and how the court of appeals would decide the case, he acted cautiously in enforcing the decree. See pp. 1376.77 infra. Implementation during this period therefore proceeded slowly. However, it must be recognized that this was only the initial stage in the overall process of implementing the Wyatt order, and that the district court's future actions and its relationship to the defendants may change considerably after the Fifth Circuit's affirmance of its original decision. See note 221 infra.

133. For example, the personal cleanliness of the patients and the sanitary conditions of the physical plant improved enormously. Third Annual Report, supra note 123. But some wards were permeated with the odor of urine and excrement. Site observation by Diane S. Kaplan, Aug. 28, 1974. Most life-endangering conditions were removed, Third Annual Report, supra, but doors between wards and buildings continued to be locked, creating a fire hazard and imposing an unnecessarily great restriction on the residents movement. PHRC Report (Aug. 2, 1974) (on file with Yale Law Journal). Many new staff members were recruited. Defendants-Appellants' Response to this Court's [the Fifth Circuit's] Order of Aug. 20, 1974 (Sept. 18, 1974) (on file with Yale Law Journal) [hereinafter cited as Defendants' Response]; Buckley Interview, supra note 6; Tillman Interview. But there remained staff members who expressed regret that they were no longer able to use "training wands," rods which deliver an electric shock to the person touched. Interview with Partlow staff member at Partlow, in Tuscaloosa, Ala., Aug. 28, 1974. Patientstaff ratios were improved, Defendants' Response, supra, thus improving supervision, but PHRC members continued to receive reports that "seclusion rooms" were being used, even though they were prohibited by the decree. Tillman Interview, supra. Most patients received planned habilitation programs, and some participated in classroom activities directed toward teaching self-proficiency skills, sewing, singing, coloring, and recreational games. Site observation by Diane S. Kaplan, Aug. 28, 1974. But the habilitation programs were limited, and most of the waking hours of many patients were spent in rocking chairs. Keever Interview, supra note 6; Tillman Interview. The major change that the decree brought these persons was that they previously sat on benches. Report of the Human Rights Committee for Partlow State School and Hospital (Apr. 2, 1973) (on file with Yale Law Journal).

The population of Partlow decreased from 1965 residents on Dec. 21,1971 , to 1878 residents on Jan. 18, 1973. Reports of Alabama Mental Health Board, Marable v. Alabama Mental Health Bd., 297 F. Supp. 291 (M.D. Ala. 1971). 
fringed. ${ }^{134}$ It did not vest the HRC's with direct responsibility for implementing the decree. Rather, that responsibility was clearly left with the defendants, and each HRC was instructed not to interfere with the administration of the institution. ${ }^{135}$

The composition of the Partlow Human Rights Committee followed what might be termed a "commission" model; it was comprised of lay persons chosen to represent a broad spectrum of the community, and in this regard was similar to many executive-appointed commissions. ${ }^{136}$ The PHRC included a minister, ${ }^{137}$ a newspaper editor, ${ }^{138}$ and three parents of institutionalized, mentally impaired children-one of whom was in Partlow. ${ }^{139}$ All members of the PHRC had been active in mental health organizations, or had otherwise demonstrated their concern for mental health care. ${ }^{140}$ However, the committee did not include any mental health professionals. ${ }^{141}$ One post on the Partlow Human Rights Committee was set aside for a resident, or former resident, of the institution. ${ }^{142}$ The effect of having such a person on the committee cannot be overemphasized, because of the type of information which an "insider" is able to provide. For example, when the PHRC was discussing the use of seclusion rooms to "cool off" unruly residents, the former resident serving on the committee stated that the major problem with seclusion rooms was that they contained electrical outlets

134. 344 F. Supp. at 376; Dinsmore Interview, supra note 6; Heilpern Intervicw; Keever Interview; Lorincz Interview; Murphy Interview; Pernell Interview; Tillman Interview; Wagnon Interview.

135. McCafferty Letter, supra note 79 , at 3.

136. See, e.g., New YoRK State Special Comm'n, Attica: The Official Report xxiv-xxv (1972) (describing the selection of a commission by the Chief Judge of the New York Court of Appeals, for appointment by the Governor, to investigate the uprising at Attica Correctional Facility).

137. Rev. Robert Keever, Chaplain, University Presbyterian Church, University of Alabama, Tuscaloosa, Ala. See 344 F. Supp. at 407. Rev. Keever was succeeded on the PHRC by Rev. James Pernell, former voluntary chaplain at Partlow, now Reverend of the Eastern Hills Baptist Church, Tuscaloosa, Ala,, Keever Interview, supra note 6; Pernell Interview.

138. Paul R. Davis, then editor of the Tuscaloosa News, Tuscaloosa, Ala. See 344 F. Supp. at 407.

199. Dinsmore Interview, supra note 6; Mathews Intervicw; Tillman Interview.

140. Dinsmore Interview, supra note 6; Keever Interview; Lorincz Interview; Mathews Interview; Pernell Interview; Tilman Interview; Wagnon Interview.

141. Dr. Andrew Lorincz, who was appointed to the PHRC approximately one year after its inception, is a pediatrician specializing in mental retardation. Lorincz Interview, supra note 6 .

142. This position was first held by Eugene Ward, then a 26-year-old Partlow resident whose court-ordered diagnosis and evaluation tested his I.Q. at 105 . Judge Johnson immediately appointed him as the resident member of the PHRC. Shortly thereafter, Ward was discharged from the institution. Several months later, the position was filled by James "Sunshine" Smith, a lifetime resident of Partlow whose I.Q. was also tested at above mental retardation levels. Shortly thereafter, Smith was discharged from the institution. However, because he continued to work within the institution, Judge Johnson granted permission for him to stay on the PHRC. See PHRC Report (July 9, 1973); Tillman Interview, supra note 6. 
which posed a danger to residents' safety. This point had been overlooked by the other Partlow Human Rights Committee members. ${ }^{143}$

The major shortcoming of the PHRC was that it lacked a full-time staff to monitor the institution continuously. The committee indicated awareness of this problem in its request to the court for authorization to hire full-time salaried "patient advocates," consideration of which was deferred until appellate review of the case was completed. ${ }^{144} \mathrm{~A}$ second constraint on the effectiveness of the committee was the absence of a mental health expert among its members. Although the committee often called upon consultants for assistance, ${ }^{145}$ many members felt handicapped by the lack of expertise. ${ }^{146}$

The court did not clearly define the powers of the Human Rights Committees, ${ }^{147}$ but instead simply issued instructions that the committees were to have full access to the institutions and were to report their findings to the court. ${ }^{148}$ The committees were not given the authority to issue subpoenas, to swear witnesses, or to make recommendations to the court, ${ }^{140}$ powers almost always assigned to masters or receivers appointed by a court to aid in the formulation or implementation of a decree. ${ }^{150}$ This left the committees, at their inception, to rely primarily on the forcefulness and resourcefulness of their members.

Although the committees were not formally granted legal powers, the Partlow Human Rights Committee proved quite effective in furthering implementation of the decree. In the early stages of implementation, the PHRC, somewhat unsure of its porwer, used its authority in several basic ways. First, the PHRG conducted its biweekly meetings like hearings by calling upon institutional staff and residents to report on violations of the decree. Because the PHRC was an arm of the federal judiciary, staff members were reluctant to refuse an "invitation" to appear before the committee. ${ }^{151}$ Similarly, although

143. PHRC Report (Aug. 23, 1974).

144. Letter from Judge Johnson to Harriet Tillman, Apr. 18, 1974 (on file with Yale Law Journal); Letter from Harriet Tillman, Chairperson, PHRC, to Judge Johnson, Apr. 15, 1974) (on file with Yale Law Journal).

145. See, e.g., Roos Progress Report, supra note 74; P. Adams \& R. Ollendorff, Report to the Human Rights Committee for Partlow State School and Hospital (May 21, 1973) (on file with Yale Law Journal); letter from James D. Clements, M.D., Director of the Georgia Retardation Center, Atlanta, Ga., to Judge Johnson, June 11, 1973 (on file with Yale Law Journal).

146. Dinsmore Interview, supra note 6; Mathews Interview; Pernell Interview; Tillman Interview; Wagnon Interview.

147. 344 F. Supp. at 376 .

148. McCafferty Letter, supra note 79.

149. Id.; 344 F. Supp. at 376.

150. See Note, supra note 23, at 106-13.

151. Buckley Interview, supra note 6 . 
these persons were not formally sworn as witnesses, they were disinclined to lie to the committee, whose reports they knew would be sent directly to the court. ${ }^{152}$ Second, by filing its regular reports with the court, the PHRC elicited from the defendants prompt responses and continued activity. ${ }^{153}$ This may have occurred because the defendants were uncertain about the exact nature of the PHRC's powers, and thought it ill-advised to ignore PHRC reports and recommendations to the court. Third, the PHRC made effective use of the press to expose unconstitutional conditions in the institution and to publicize changes that were made. This was done largely through the editor of a local newspaper, who was a member of the PHRC ${ }^{154}$ and wrote signed articles about the institution. ${ }^{155}$

Through this last method, the PHRC developed powers analogous to executive-appointed commissions, which, as noted, its composition resembled. ${ }^{150}$ Commissions rarely have any authority to order changes in the subject matter of their investigation. Instead, like ombudsmen, ${ }^{157}$ they indirectly influence decisionmakers through publicizing findings and alerting responsible administrators to abuses which must be corrected, During the early stages of the Wyatt implementation, when the court maintained a low profile, the PHRC's power was exercised in a similarly indirect fashion.

In the later stages of implementation, the PHRC began to avail itself of the legal powers of the court. ${ }^{158}$ When the administration began to refuse the PHRC access to staff members and files, the committee obtained an order from the court instructing the defendants to cooperate. ${ }^{150}$ This order was supported by the same power of contempt

152. Id.

153. See, e.g., Defendants' Response to Order to Show Cause (July 24, 1974) (on file with Yale Law Journal).

154. See note 138 supra.

155. See, e.g., Davis, Record Funds Okayed for Mental Health Programs, Tuscaloosa News, Aug. 17, 1973, at 1, col. 8; Davis, Ira DeMent Could Be New Commissioner, Tuscaloosa News, Oct. 18, 1973, at 6, col. 7 .

The chairperson of the Searcy Human Rights Committee has written that the major contribution of that committee has been in publicizing hospital conditions and bringing the need for reform to the attention of the public and the state legislature. See Developments-Civil Commitment, supra note 5, at 1340-41 n.103.

156. See p. 1361 supra.

157. See note 32 supra.

158. Interviews with PHRC members indicated that they never saw the committee as a body with legal powers. Dinsmore Interview, supra note 6; Mathews Interview; Tillman Interview. The committee's use of the court's legal powers was more a result of the change in how the court responded to reports and requests from the PHRC than of any change in what the PHRC requested the court to do.

159. Order (Sept. 26, 1974) (on file with Yale Law Journal). This order was not specifically requested by the PHRC; the committee simply brought the problem to the attention of the court, which then issued the order. 
that would be used to enforce a subpoena issued by a traditional master or receiver. Toward the end of the two year implementation period the court issued an order ${ }^{100}$ requiring the defendants to show cause why they had not complied with the PHRC's recommendations even though some of these recommendations were not explicitly covered by the original decree. ${ }^{161}$ Thus, the PHRG's continued access to the court enabled it to rely upon powers similar to those of a master or receiver responsible for implementation, and to play a role beyond that of serving as the "eyes and ears" of the court.

\section{The Plaintiffs, Amici, and Their Lawyers}

The adjudication of structural injunctions generally places heavy burdens on the lawyers involved in a case, during both the trial and implementation stages. Judge Johnson recognized this early in the Wyatt litigation when he ordered the United States, through the Department of Justice, to enter the suit as amicus curiae, ${ }^{162}$ and gave leave to several national mental health organizations to participate jointly as amici. ${ }^{163}$ The United States and the mental health amici assumed some of the burden during the trial and implementation that might otherwise have fallen on the local counsel who represented the plaintiffs.

The local counsel who filed the original complaint continued to represent the plaintiff patients throughout implementation. ${ }^{164}$ At the beginning of implementation, one of the local attorneys conducted several of the first PHRC meetings, ${ }^{105}$ and contributed to the committee's aggressive, almost adversarial stance toward the administration. ${ }^{168}$ The local counsel remained in close contact with the Partlow Human Rights Committee, and on the basis of information received from it, petitioned the court for relief in two specific areas-application of the Fair Labor Standards Act to patient labor, ${ }^{167}$ and prohibition of involuntary sterilizations. ${ }^{168}$ However, the unsettled question of the

160, Order to Show Cause (June 25, 1974) (on file with Yale Law Journal); Defendants' Response to Order to Show Cause (July 24, 1974) (on file with Yale Law Journal).

161. Compare Third Annual Report, supra note 123, with 344 F. Supp. 387.

162. See 334 F. Supp. at 1343 n.2.

163. Order (Aug. 20, 1971).

164. Dean' Interview, supra note 6.

165. Dean Interview, supra note 6; Tillman Interview.

166. Tillman Interview, supra note 6.

167. Motion for Specific Enforcement of Prior Orders or in the alternative or conjunctive Motion to Show Cause Why Defendants Should Not Be Held in Contempt (July 5,1972 ) (on file with Yale Law Journal).

168. Amended Complaint or alternatively Motion for Further Relief (July 24, 1973) (on file with Yale Law Journal). 
right to collect attorneys' fees from the defendants ${ }^{169}$ constrained the plaintiffs' lawyers in two ways from continuing an active role in implementation. Although the district court awarded attorneys' fees, the funds were impounded pending appeal, ${ }^{170}$ thereby placing the local lawyers under a financial strain. In addition, the issue of attorneys' fees generated animosity between the plaintiffs' lawyers and the defendants. At least one defendant state official went so far as to charge that the prospect of attorneys' fees was the reason for the filing of plaintiffs' post-decree motions. ${ }^{171}$

The United States, as amicus, performed several distinct roles, some of considerable value. First, the Justice Department was designated by the court to provide legal counsel to the Partlow Human Rights Committee. ${ }^{172}$ Moreover, the Federal Bureau of Investigation was able to provide investigatory assistance to the $\mathrm{PHRC},{ }^{173}$ which enabled the committee, as an instrument of the court, to present its views to the district court in a more complete form than otherwise would have been possible. Finally, the Justice Department also represented the views of the executive branch of the federal government. In particular, although implementing the decree never required the court to call upon the federal government for assistance, the presence of the United States as amicus may well have helped to avoid such a crisis. Judge Johnson had prior experience in utilizing the Justice Department in an amicus role: he had ordered the United States to participate as amicus in a school desegregation case. ${ }^{174}$ When the state refused to comply with

169. When the Fifth Circuit affirmed Wyatt on the merits, it reserved decision on the award of attorneys' fees to plaintiffs pending decision on the same issue in other cases before that court. 503 F.2d at 1319 .

170. Supplemental Brief of Amici Guriae American Psychiatric Ass'n, American Psychological Ass'n, American Orthopsychiatric Ass'n, American Civil Liberties Union, American Ass'n on Mental Deficiency, National Ass'n for Mental Health, and National Ass'n for Retarded Citizens at 2 (Sept. 20, 1974) (on file with Yale Law Journal); Dean Interview, supra note 6; Drake Interview; Halpern Interview; Humphries Interview.

171. Humphries Interview, supra note 6 .

172. Letter from Judge Johnson to Ira DeMent, U.S. Attorney, July 20, 1972 (on file with Yale Law Journal). In this letter of appointment, Judge Johnson stated:

Since the members of the Human Rights Committees were appointed by this Court, they are officials of the Court, acting under and by the authority of the Court. For this reason $I$ do not think it is appropriate that they be represented in the case by their own counsel or by counsel already appearing for one of the active litigants. It is appropriate, however, that they be represented by one of the amici, and I hereby request that you represent the Bryce and Partlow Committees... in any ... matters where they need legal representation and guidance. Id. at 1 .

173. PHRC Report (Dec. 11, 1972) (on file with Yale Law Journal); DeMent Interview, supra note 6; Tillman Interview.

174. Carr v. Montgomery County Bd. of Educ., 232 F. Supp. 705, 706 (M.D. Ala. 1964); Order (May 18, 1964) (appointing the U.S. Attorney and John Doar, Attorney, Civil Rights Div., Dep't of Justice, as amici curiae "to assist the Court in the speedy and just determination of the issues"), reprinted in $O$. Fiss, InJuncrions 417 (1972). 
the court's orders, the federal executive branch did not hesitate to step in. ${ }^{175}$ Hence, in Wyatt there was no doubt in the minds of the court or of the parties that the United States would intercede if requested.

The mental health amici performed an active role at the trial stage in the production of expert testimony and the development of standards for adequate treatment. However, they did not actively participate in implementation, but merely remained in contact with the plaintiffs' lawyers and the Partlow Human Rights Committee. ${ }^{178}$

In sum, despite the assistance provided in specific areas by the lawyers for the plaintiffs, United States, and mental health amici, the PHRG bore the primary burden and responsibility for monitoring implementation and protecting the rights of the plaintiffs. The court undoubtedly anticipated this when it first appointed the three Human Rights Committees. However, more active participation by the attorneys for the plaintiffs and amici might have compensated for some of the deficiencies of the Partlow Human Rights Committee that emerged during the implementation process, especially its lack of staff. ${ }^{177}$ For example, because one of the major shortcomings of the PHRC was its need to rely on the defendants for much of its informa-

175. See, e.g., United States' Motion for Supplemental Relief (Feb. 7, 1968), Carr v. Montgomery County Bd. of Educ., 232 F. Supp. 705 (M.D. Ala. 1964), reprinted in 0. Fiss, Injunctions 459 (1972).

176. Dean Interview, supra note 6; Drake Interview; Halpern Interview; Tillman Interview.

177. Greater involvement with the PHRC by the attorneys for the plaintiffs or for the mental health amici would have carried with it the danger that the PHRC would become more partisan and lose some of its independent status as an arm of the court.

In an order issued several months after affirmance of the case by the Fifth Circuit, Judge Johnson made clear that he did not want the lawyers for the plaintiffs to become involved with the Partlow Human Rights Committee:

Insofar as the relationship of the Court, committees, and counsel for the parties is concerned, it appears that plaintiffs' counsel misapprehend the nature of the role they play at this stage of the proceedings in this lawsuit. Although it was their responsibility to seek the entry of a judgment and decree which was favorable to the clients whom they represent and it is their continuing responsibility to protect the interests of said clients, it is the responsibility of this Court to ensure that its orders are complied with and its decrees implemented. Whatever function counsel should perform in the implementation process is a function whose scope is properly defined by the Court whose judgment is being implemented or enforced. The role of the Human Rights Committees in the implementation of the orders in this case and their relationship with this Court have been the subjects of a number of orders, supra, letters, and other types of communication and continue to constitute part of the on-going dialogue which the Court maintains with the committees. If the Human Rights Committees, or any member thereof, fail in the performance of their functions to reflect the philosophy of the Court insofar as the enforcement and imple. mentation of the court decrees in this case, then the Court will either reconstitute the committee(s) or terminate the member(s) whose philosophy and/or actions do not aid in the Court's implementation and enforcement of its orders. In any cvent, this is strictly a court function-not a function of the parties or the counsel.

Order (April 2, 1975) (on file with Yale Law Journal) (order did not specify whether these admonitions were directed to counsel for the mental health amici as well as the counsel for the plaintiffs). 
tion about what was occurring inside the institutions, the committee would have been greatly aided by the use of the amici mental health organizations as experts to conduct thorough, independent investigations of changes within the institution. Similarly, although a strong chairperson was able to give some guidance to the PHRC, such expert advice would have provided the committee with direction and some sense of priority as to which standards of the decree warranted immediate implementation and which could or should be deferred. However, the lawyers for the plaintiffs and amici refrained from assuming an active stance, for they took literally Judge Johnson's statements that he would not entertain motions for further relief until the case had been affirmed by the Fifth Circuit. ${ }^{178}$ Furthermore, the lawyers may have thought that the monitoring of implementation by the PHRC made their participation less imperative.

\section{The Defendants}

The defendant state officials were often faced with conflicting choices and loyalties in the Wyatt implementation. Political considerations caused them to oppose any effort by a federal court to assume responsibility for the administration of a state institution. Professional considerations led them to agree with most of the substantive goals of improved treatment which were ultimately embodied in the decree.

Stonewall B. Stickney, Commissioner of Mental Health when Wyatt was filed, has written that the Mental Health Board opposed the intervention of the federal judiciary into state mental health programs and sought vigorously to maintain its own control over the institutions. However, its agreement with the substantive goals of the decree is evidenced by the fact that when the Court ordered the parties to submit proposed minimum standards for adequate treatment, the defendants, plaintiffs, and mental health amici were able to agree on and stipulate over 90 percent of the required standards. ${ }^{170}$ Moreover, once the court recognized that a right to treatment existed, Dr. Stickney began to regard the decree as a method of obtaining increased financial support from the Governor and state legislature. ${ }^{180}$ He saw the court's

178. Dean Interview, supra note 6; Drake Interview; Halpern Interview.

179. Amici's Appeal Brief, supra note 56, at 10 . While the defendants stipulated to most of the standards, they were not sure that they would have the financial resources to implement them. When Dr. Stickney was asked in an interview whether the stipulations were entered into in "good faith," he replied, "We had no choice. We were ordered to come up with standards." Stickney Interview, supra note 6.

180. Stickney Article, supra note 73; cf. Pennsylvania Ass'n of Retarded Children v. Pennsylvania, 343 F. Supp. 279 (E.D. Pa. 1972); Kirp, Buss \& Kuriloff, supra note 24, at 59. 
"broad hinting" at judicially ordered financing as a tool he could use to convince the legislature that it should voluntarily increase its funding. ${ }^{181}$

A similar ambivalence was evident in the Partlow administration. The Partlow Superintendent alternately regarded the decree as enhancing his power and as interfering with his professional judgment. ${ }^{182}$ He stated that because the court order placed the authority of the federal judiciary behind him, he was able to "stand up" to staff members, members of the community, and politicians who objected to actions he took as Superintendent. But he hastened to add that the Partlow Human Rights Committee as constituted was an encroachment upon his administrative prerogative. He felt that his administration was in a better position than the PHRG to protect the rights of residents, and that a great deal of the progress within the institution would have been made without the court's decree due to the emphasis placed on improving Alabama's mental institutions during the administration of Governor Lurleen B. Wallace. ${ }^{183}$

The Superintendent's use of the court order to strengthen his hand in relation to the staff has had some detrimental effects. One of the major problems in implementation has been resistance to the decree by both professional and nonprofessional staff members-especially those who have worked in the institution a long time. These staff members have been suffering an "extinction reaction," a perceived loss of control which they formerly exercised over the residents. By justifying his actions on the ground that they were compelled by the court decree, the Superintendent indirectly endorsed the staff's view that the decree was an intrusion upon the institution and an unjustified limitation on both the staff's and the administration's authority. As a result of this "extinction reaction," there have been reports of some personnel becoming more abusive to the patients since the issuance of the decree; moreover, the already strong solidarity among many staff members has

181. Stickney Article, supra note 75; Stickney Interview, supra note 6. In Wyalt, the agreement between the parties did not come until after the court had held that there was a constitutional right to treatment and that the three institutions did not meet constitutional standards. The court then ordered the parties to negotiate to develop standards. Such an agreement, if reached at an earlier stage of the litigation, may in effect makc the lawsuit collusive; moreover, an agreement between the state executive and private parties, endorsed by the judiciary, to arrogate the state legislature's power to appropriate funds, would raise serious problems concerning separation of powers. See $503 \mathrm{~F} .2 \mathrm{~d}$ at 1317; $c f$. H.M. Hart \& H. Wechsler, The Federal Courts and the Federal Systeng 106 (2d ed. 1973).

182. Buckley Interview, supra note 6 .

183. Id.; 344 F. Supp. at 393 n.12. A similar position was taken by Gov. George C. Wallace on appeal. Brief of Gov. George C. Wallace at I (October 1972) (on file with Yale Law Journal) [hereinafter cited as Brief of Gov. Wallace]. 
increased, producing a "no-ratting" policy whereby many staff members do not report incidents that reflect poorly on others. ${ }^{184}$

The Partlow Superintendent would have preferred a differently constituted body to perform certain aspects of the PHRC's role. In his view, the only necessary function was the reporting of information to the court, which could best be done by a committee comprised solely of mental health professionals who would evaluate data supplied by the administration. ${ }^{185}$ However, the considerable conflicts and struggles for information and access that have punctuated the implementation process suggest that there was a significant need for the independent monitoring function served by the PHRC.

Governor George C. Wallace, who filed a separate appeal in Wyatt and filed unsuccessful motions to stay the decree pending appeal, ${ }^{180}$ had little direct impact on implementation. Although the Governor declined to honor Judge Johnson's suggestion to call a special session of the legislature, ${ }^{187}$ he did release eleven million dollars of Alabama's revenue sharing funds to the Mental Health Board. ${ }^{188}$ The Governor's dual position on appeal-supporting the substantive goals of the decree while opposing the issuance of the decree and the intervention of the federal court ${ }^{180}-$ minimized whatever influence he might otherwise have had on the implementation process. The only apparent effect was that the Governor's equivocal support of the Wyatt decree permitted certain individuals within Partlow's administration and staff to deny the legitimacy of the PHRG and therefore justify their own lack of co-operation with the committee.

\section{General Problems During Implementation}

\section{Evaluating Compliance With the Decree}

A recurring question throughout the implementation process was whether the court, the Partlow Human Rights Committee, and the

184. Buckley Interview, supra note 6; Scales Interview.

185. Buckley Interview, supra note 6 .

186. Motion [of Defendant George C. Wallace] for Stay of Execution Pending Appeal (May 22, 1972) (on file with Yale Law Journal); Order (June 26, 1972) (denying motion) (on file with Yale Law Journal); Order (Aug. 15, 1972) (U.S. Court of Appeals denying motion).

187. 344 F. Supp. at 378 n.8.

188. Defendants' Response, supra note 133.

189. The Governor's brief was marked by a self-professed agreement with the "ultimate achievement of the standards and goals for mental health facilities which are set forth in the District Court's Order of April 13, 1972," along with a deep disagreement with the role assumed by the court in formulating and implementing the decree. Brief of Gov. Wallace, supra note 183 , at $\mathrm{i}$. 
parties could ascertain the extent to which the institution was in compliance with the decree. The answer to this question depended on obtaining accurate information about what was in fact happening in the institution, and on being able to evaluate those facts against the requirements of the decree.

Obtaining Accurate Information. There were only two basic sources of information available to the court on what changes occurred in Partlow during the implementation period-reports filed with the court by the defendants, and reports prepared by the Partlow Human Rights Committee..$^{190}$ Neither was completely reliable.

The defendants used only the normal bureaucratic institutional channels to compile information on compliance. Because there was a self-interest in showing compliance at every level of the institutional bureaucracy-from ward staff to administrator-the accuracy of the reports was inherently suspect.

While the Human Rights Committees-at Partlow and the other two institutions-had the independence necessary to ensure an accurate report, they did not have the resources to do so. Because the Partlow Human Rights Committee had no staff, it relied primarily on information obtained during observation visits made to the institution by committee members, ${ }^{191}$ and on information from institutional staff members, patients and patients' families, conveyed both formally at the PHRC meetings and informally in phone calls. ${ }^{102}$ These sources of information were sporadic and incomplete and there was no continual or internal monitoring system.

In addition to these methods, the Partlow Human Rights Committee used two other approaches to obtain information about what was happening in the institution. The PHRC hired several professional consultants to advise it about some of the most serious problems remaining in the institution. ${ }^{193}$ However, while these consultants' reports were comprehensive and impartial, they only covered short periods of time and therefore did not provide a complete picture of the changes in the institution after the issuance of the decree. The

190. The PHRC filed reports approximately bi-weekly, after each committee meeting. As ordered by the court, the defendants filed a progress report after the first six months. Defendants' Report to the Court Concerning Partlow State School and Hospital (Oct. 10, 1972) (on file with Yale Law Journal). Annual reports were filed thereafter. See Progress Report of the Partlow State School and Hospital (June 1, 1973) (on file with Yale Law Journal).

191. Keever Interview, supra note 6; Mathews Interview; Pernell Interview; Tillman Interview.

192. Tillman Interview, supra note 6.

193. See note 145 supra. Some of these consultants had been called as expert witnesses during the hearings. See, e.g., Roos Testimony, supra note 56. 
PHRC also utilized the Federal Bureau of Investigation, but with only limited success, to obtain information about compliance with those standards that were directed toward protecting residents from physical abuse, excessive punishment, or unnecessary indignities. ${ }^{194}$

Therefore, because of the inadequacies of these methods, there existed no thorough, independently developed data on the extent of implementation or the level of compliance attained in the institutions at the time that the Wyatt case was affirmed by the Fifth Circuit. ${ }^{105}$

Evaluating the Facts Against the Requirements of the Decree. Even when accurate facts were obtained, there was an inherent difficulty in evaluating these facts against the requirements of the decree. This difficulty resulted in part from the fact that the decree embodied potentially conflicting goals which represent two divergent mental health philosophies. One favors a transition from institutionalization to the "least restrictive alternative" setting for treatment, ${ }^{106}$ so that the only persons who would be institutionalized are those who cannot receive adequate treatment in a setting which places fewer restrictions on their liberty. The other proposes a restructuring of the institutions to make them more humane, but supports maintenance of the basic institutional framework.

On its face, the decree does not express a preference for either of these philosophies. Neither the court, the parties nor the amici directly addressed the question of whether the choice between the two approaches was a constitutional one, appropriately made by the court, or a professional one, properly left to the discretion of the state officials. ${ }^{197}$

194. PHRC Report (Dec. 11, 1972) (on file with Yale Law Journal). The FBI investigation was prompted by complaints received by PHRC members which alleged that institutional personnel were physically abusing patients. While the FBI did not determine the cause or extent of these abuses, the complaints ceased about the time of the investigation, and it is possible that the presence of the FBI in the institution deterred abusive conduct, or, conversely, deterred reports of such conduct. Buckley Interview, supra note 6; Tillman Interview. At the behest of the Justice Department, the FBI was utilized at Bryce and Searcy Hospitals to obtain information on changes in those institutions since the issuance of the decree. Instead of developing independent data, the FBI relied almost exclusively on information supplied to them by the hospital administrations. Interview with Diane Dorfman, Attorney, Civil Rights Div., Dep't of Justice, in Montgomery, Ala., Aug. 29, 1974.

195. Supplementary Report of Amicus Curiae United States of America at 3 (Sept. 20, 1974) (on file with Yale Law Journal).

196. See Chambers, Right to the Least Restrictive Alternative Setting for Treatment, in 2 P.L.I., Legal Rights of the Mentally Handicapped 91 (B. Ennis, P. Friedman \& B. Gitlin eds. 1973).

197. The most important legal difference between the two philosophies, and the key to whether the choice is a constitutional or a professional one, is the manner in which they relate to the constitutional basis of the right to treatment-that the due process clause requires treatment as the quid pro quo for involuntary commitment. See note 2 supra. The philosophy which favors institutional reform maintains that institutionalization can meet due process standards as long as adequate treatment is provided. The 
The failure of the court to resolve this issue made it difficult to evaluate whether overall institutional changes furthered long-range compliance with the decree. For example, virtually all of the expenditures made to comply with the decree were directed toward improving treatment within the existing institutions. ${ }^{198}$ Reports filed with the court and extensive interviews have provided no indication that the defendants ever considered the alternative of abandoning the institutions entirely and devising other methods of providing adequate treatment, such as small, community treatment centers which might provide more effective care at a lower cost and with a lesser deprivation of liberty. ${ }^{199}$ While the capital expenditures made in the institutions were not great enough to foreclose a possible long-range goal of deinstitutionalization, ${ }^{200}$ the effect was to generate momentum toward institutional reform rather than deinstitutionalization. Hence, if it is later held that deinstitutionalization to the least restrictive alternative is constitutionally compelled, the changes made in the institutions will not have advanced the state mental health system toward that goal.

Beyond this inherent ambiguity in the court's order, there existed further difficulty in assessing compliance with the judicial mandate. Most of the individual standards of the decree could be objectively quantified, and compliance with the specific requirements was simple to evaluate on a standard-by-standard basis. For example, compliance with standards which established staffing ratios for the professional and nonprofessional staff, maximum numbers of residents allowed to be housed in a ward, and specifications for the renovation of buildings,

\footnotetext{
philosophy which endorses a transition to the least restrictive alternative setting for treatment argues that institutionalization can only meet due process standards if no less drastic intrusion on the patient's liberty can provide adequate treatment. $C f$. Covington v. Harris, 419 F.2d 617, 623-24 (D.C. Cir. 1969) (dictum).

198. Defendants' Response, supra note 133; Buckley Interview, supra note 6. The counsel for the Mental Health Board stated in an interview that the Board would not release capital funds for noninstitutional facilities until ordered to do so by the court. Humphries Interview.

199. Dean Interview, supra note 6; Dinsmore Interview; Keever Interview; Tillman Interview. $C f$. New York State Ass'n for Retarded Children v. Carey, Civil No. 72-356, 357 (E.D.N.Y., Apr. 30, 1975) (consent decree), which provides for virtually complete deinstitutionalization of mental patients in New York's Willowbrook Development Center. Willowbrook, which contained more than 5,000 patients before this litigation began, will have its patient population reduced to 250 . The consent decree would set up 200 community places for patients in the first year-hostels, halfway homes, workshops, and day-care training centers. Most community centers would be limited to 25 resident patients. N.Y. Times, Apr. 22, 1975, at 1, col. 2.

200. In the three fiscal years covered by the decree to date, ending 1972 through $1974, \$ 1,280,451.40$ was spent on capital improvements at Partlow-primarily to eliminate fire hazards, partition bathrooms, and install air-conditioning. In comparison, the annual operational expenses of Partlow were: 1971-72, \$8.8 million; 1972-73, \$13.2 million; and 1973-74, \$15.4 million. Defendants' Response, supra note 133, at 6 .
} 
can usually be evaluated without any subjective judgment. ${ }^{201}$ However, it became much more difficult to evaluate compliance when one considered the interaction of the various standards and the cumulative impact of the changes made in the institution. For example, the parties generally recognized that probably the most important of the standards was the requirement that the institution develop individualized habilitation programs for the residents. As one member of the Bryce Human Rights Committee stated, "Individual habilitation plans are the keystone to successfully implementing the substance of the decree because everything that is to be done to and for a patient is determined by these plans."202 Therefore, if one evaluated compliance with a given standard, such as staffing ratios in a particular ward, without considering whether the residents had individualized habilitation plans, the evaluation would be distorted. It would neglect to consider that even though the staffing ratios might have been improved, one could not be sure without the individualized habilitation plans that the staff knew the specific needs of each resident, or that the increase in the number of staff improved the care of the residents.

The ability of the Partlow Human Rights Committee, and therefore of the court, to evaluate compliance ultimately depended upon its understanding of the interrelation among the standards, the potential detrimental and beneficial effects of selective compliance, and the long-range implications of stopgap measures. While the PHRC was able to measure compliance on a standard-by-standard basis, its ability to determine the full impact of the changes was limited because few committee members possessed the expertise necessary to gain the requisite understanding. ${ }^{203}$

\section{The Need for Continuing Judicial Superivision}

Ascertaining the Scope of the Decree. When the Wyatt decree was issued it was viewed as comprehensive by all parties. However, as implementation progressed, serious problems about the scope of the decree arose over two issues: whether the decree protected the rights of residents after their discharge from the institutions, and what would

201. However, even compliance with a mathematical standard like a staffing ratio may sometime be deceptive. Jack Drake, co-counsel for the plaintiffs, commented, "Statistics lie because there is a large number of professionals doing administrative work; not caring for patients. Patient-staff ratios are therefore of questionable value." Drake Interview, supra note 6.

202. Wagnon Interview, supra note 6.

203. Mathews Interview, supra note 6; Pernell Interview; Tillman Interview; Wagnon Interview. 
be done if abuses not contemplated in the original complaint or the decree were uncovered in the course of implementation.

Because some PHRC members became concerned that certain former residents had not been properly placed outside the institution but instead were "dumped" into the community, ${ }^{204}$ the Partlow Human Rights Committee raised the question of whether the decree, and the committee's responsibility, extended to residents who had been discharged from the institution. ${ }^{205}$ In response to a PHRC request for clarification of its responsibility, the district court explicitly restricted the committee to the institution. ${ }^{206}$

Because the PHRC was the only method the court had to supervise the decree, this restriction effectively limited the scope of the decree to the institution's walls. Yet it was clear that problems existed with residents released from the institution. Storekeepers in local communities complained of former residents engaging in such conduct as urinating on the floors, opening up and using packages of make-up, and bouncing on beds in furniture stores. ${ }^{207}$ Discharged residents allegedly engaged in improper sexual behavior, leading to complaints and criminal charges. ${ }^{208}$ Citizens of one town in Alabama applied for and were granted a state court injunction to close a halfway house for residents discharged from one of the Wyatt institutions, alleging that the house was so badly supervised that it constituted a nuisance which devalued local property. ${ }^{209}$ The lack of adequate post-institutional placement and followup was also evidenced by complaints received by the Alabama Mental Health Board from local mental heath organizations, which stated that Partlow residents had been inappropriately

204. Tillman Interview, supra note 6; Wagnon Interview.

205. Tillman Interview, supra note 6. See note 93 supra.

206. Dinsmore Interview, supra note 6; Mathews Interview; Tillman Interview; Wagnon Interview. But see note 221 infra.

207. Wagnon Interview, supra note 6.

208. PHRC Report (Feb. 4, 1974) (on file with Yale Law Journal); PHRC Report (Mar. 16, 1974). One severely retarded resident who was released into the community was arrested and charged with child molesting. PHRC Report (Apr. 16, 1973) (on file with Yale Law Journal). At his competency hearing, the former Partlow resident was committed by the local court back to Partlow "until such time as he is found to be competent to stand trial." Alabama v. Wigley, No. 3587-B (6th Jud. Cir. Ct., Ala., Apr. 15, 1974) (on file with Yale Law Journal). The patient had been advised by Partlow staff members that he had the alternative of standing trial and probably going to jail, or returning to Partlow. Not wanting to go back to Partlow, and having had placement in a halfway house foreclosed, the resident said that he preferred jail. Nevertheless, because he was deemed incompetent to stand trial, he was committed to Partlow. Memorandum from James Allen, Social Director of Partlow State School and Hospital, to Dr. Richard Buckley, Superintendent, Apr. 2, 1974.

209. Bankston v. Smith, No. 32,015 (23d Jud. Cir. Ct., Ala., Mar. 5, 1974) (on file with Yale Law Journal). The case was appealed to the Supreme Court of Alabama, and the state Mental Health Board entered the case as amicus in support of the defendants. Humphries Interview, supra note 6. 
placed under their care in facilities that were not suited to meet those persons' needs. ${ }^{210}$

The district court's decision to limit the PHRC's jurisdiction to the institution was probably founded on well-intentioned beliefs that the problems should be attacked one at a time. However, the court apparently failed to anticipate that the decree itself would create problems outside the institution, through the discharge of residents, and thus did not take sufficient measures to minimize these effects. Furthermore, the decree's constitutional standards for adequate institutional treatment arguably applied to residents of the institution who were released. Discharged patients should be considered members of the class entitled to a right to treatment until they successfully reenter the community and all of the possibly adverse effects of institutionalization have been removed.211

A similar problem regarding the scope of the decree arose when outside scrutiny of the institution uncovered abuses not contemplated by the court in its order. For example, a disparity in the treatment of the races in the institution was suggested by the fact that a disproportionately large number of deaths occurred among black Partlow residents, when compared to the deaths in the resident white population. ${ }^{212}$ However, it was impossible to determine the reason for this due to the lack of accurate records on individual residents, and therefore no action was taken by the PHRC, the plaintiffs' attorneys, or the court. Nevertheless, the incident underscores the possibility of discovering abuses not encompassed by the decree which require corrective action by the court.

Unanticipated Effects of Enforcement. Because the Wyatt decree required massive institutional restructuring, it created the possibility that changes undertaken at one stage of implementation would have adverse effects at another stage. Problems of this nature ranged from administrative oversight of routine matters, to at least one serious error.

210. Letter from Jeff Caskey, Associate Director, Southwest Alabama Health Planning Council, to Charles Aderholt, Commissioner of Mental Health, July 31, 1973 (on file with Yale Law Journal).

211. See standard 47, 344 F. Supp. at 407 . The reason for this is that the due process obligation of the state to provide patients with a "realistic opportunity to be cured," 325 F. Supp. at 784 , is not fulfilled if the patient is returned to the community without adequate provision for the transition to normal community life.

212. PHRC Report (June 23, 1973); Lorincz Interview, supra note 6. The IVyatt decree did have one effect on race relations in the institutions. Dr. Stickney stated that implementation of the district court's earlier decree in Marable v. Alabama Mental Health Bd., 297 F. Supp. 291 (M.D. Ala. 1971), which ordered Alabama to desegregate its mental institutions, was furthered by the increased scrutiny of the institutions due to the Wyatt case. Stickney Interview, supra note 6 . 
The routine problems may well be a necessary concomitant of institutional change. For example, toilet facilities at Partlow were installed on the basis of the patient population before patients were moved from one part of the institution to another, with the result that after the moves many of the residents were without appropriate toilet facilities. ${ }^{213}$ Similarly, large numbers of untrained staff members were hired under the court order, with inadequate provision made for their training. This required experienced staff to take time from their normal jobs to instruct the new personnel, thereby temporarily reducing the level of care provided. ${ }^{214}$

A more serious problem emerged early in the implementation process. The court's decree required the institution to compensate patients for institution-maintaining labor. Shortly after the decree was entered, the Partlow Human Rights Committee began to note numerous complaints from patients who had been working without compensation before the issuance of the decree but who, after the issuance of the decree, were no longer allowed to work ${ }^{215}$ because the administration allegedly lacked the resources to pay them. ${ }^{216}$ "These residents are now bored and anxious to be doing something," the PHRC noted. ${ }^{217}$ This problem had not been foreseen by the court. It was eventually corrected by clarifying the decree to allow patients to perform uncompensated labor for therapeutic purposes. ${ }^{218}$ This incident illustrates the need for continuing judicial supervision to deal with the unanticipated effects of implementation.

\section{The Informal "Stay" Pending Appeal}

Both the district court and the Fifth Circuit declined formally to stay the district court's decree during the two year pendency of the

213. Tillman Interview, supra note 6 .

214. Stickney Interview, supra note 6 .

215. PHRC Report (June 9, 1972) (on file with Yale Law Journal).

216. Id. Standard 33 of the Partlow decree, 344 F. Supp. at 402-03, incorporated provisions of the Fair Labor Standards Act $\$ 6,29$ U.S.C. $\$ 206$ (1966), which forbids uncompensated patient labor.

217. PHRC Report (June 9, 1972) (on file with Yale Law Journal).

218. Order (Dec. 4, 1972) (on file with Yale Law Journal). This order was issucd in response to Motion for Specific Enforcement of Prior Orders, or in the alternative or conjunctive Motion to Show Cause Why Defendants Should Not Be Held in Contempt (July 5, 1972) (on file with Yale Law Journal). Ironically, the motion, filed by the lawyers for the plaintiff patients, emphasized the fact that those patients who continued to work were not compensated, while the PHRC had stressed that large numbers of patients were no longer allowed to work. Compare Motion for Specific Enforcement of Prior Orders, or in the alternative or conjunctive, Motion to Show Cause Why Defendants Should Not Be Held in Contempt (July 5, 1972) (on file with Yale Law Journal) with PHRC Report (June 9, 1972) (on file with Yale Law Journal). 
appeal. ${ }^{210}$ However, political considerations dictated that the district court exercise restraint until its decision was affirmed. Therefore, Judge Johnson let it be known 220 that he would take no additional steps to enforce the decree, either through judicially ordered financing, the appointment of a master, the expansion of the PHRC's power, or the use of the court's contempt powers, until the court of appeals approved his initial orders establishing both the right to treatment and the appropriate standards for implementing that right. ${ }^{21}$ Thus, there was effectively an informal, partial "stay" of the district court's decree.

As a result of Judge Johnson's position, little pressure was placed on the defendants to comply promptly with the court's order, and implementation therefore proceeded slowly during this period. One possible benefit of this delay was that it allowed the defendants a "grace period," thereby decreasing the friction inherent in a decree ordering institutional change.222 However, the delay in implementation was

219. See note 186 supra.

220. Tillman Interview, supra note 6; Wagnon Interview.

221. However, shortly after affirmance by the Fifth Circuit, Judge Johnson issued two orders, apparently to correct some of the problems that had emerged during the pendency of the appeal. First, Judge Johnson authorized each of the three Human Rights Committees to employ one full-time "staff specialist," e.g., a psychiatrist, to be responsible to the committee and to the court. Order (Feb. 7,1975 ) (on file with Yale Law Journal). The salary of each specialist was to be paid by the Department of Mental Health. Id. Each committee was also authorized to employ a full-time secretary, and was given office space on the premises of the institution. Id. Second, upon Motion of the Partlow Human Rights Committee (Dec. 23, 1974) the court extended the jurisdiction of the PHRC beyond Partlow's walls to "any other centers, homes, and facilities-public or private-to which retarded persons are assigned or transferred for residence by the Alabama Department of Mental Health." It similarly extended the jurisdiction of the Bryce Human Rights Committee to other institutions for the mentally ill. Order (Feb. 28, 1975) (on file with Yale Law Journal). Cf. pp. 1358, 1360 supra. However, this recent modification does not grant either of the Human Rights Committees authority to protect the rights of patients who are discharged from the institutions into the community.

222. Another potential benefit is that during this delay the Fifth Circuit could have observed what was actually happening in the institution, thereby avoiding having to answer in the abstract the question of the feasibility of the decree. However, the Fifth Circuit did not do this. The only action taken by the appellate court to serve this purpose was the issuance of an order on August 20, 1974, two and one-half months before its opinion was issued, which requested information on the current state of the institutions. Order (Aug. 20, 1974) (on file with Yale Law Journal). The order, which took the form of a "questionnaire," requested information from the parties and amici on several specific matters-the number of professional and nonprofessional staff employed in each institution, the current number of patients in the institutions, and changes in the institutions' budgets. The order also requested information on what legal actions, if any, had been taken by the district court since the issuance of the decree. The Fifth Circuit did not request to see copies of the Human Rights Committees' reports, which had been filed in the district court and which contained the most reliable information on the progress of implementation.

The mental health amici objected to this procedure, stating that it was necessary to develop the facts fully in evidentiary hearings on compliance in the district court. Supplemental Brief of Amici Curiae, supra note 170, at 3-4 (Sept. 20, 1974). However, it is common practice for appellate courts to ascertain informally from counsel what, if any, facts have changed since the lower court record was completed. In cases decided promptly, 
widely regarded by members of the Human Rights Committees, ${ }^{223}$ and attorneys for the plaintiffs ${ }^{224}$ as frustrating the purposes of the decree. Because the two year "stay" substantially impeded the implementation process in Wyatt, courts ought to consider carefully the effect that a protracted delay in decision will have on their ultimate ability to render appropriate relief.

\section{Conclusion}

Experience in implementing the Wyatt decree during the two year pendency of the appeal has underlined the importance of continued judicial responsibility for the implementation of decrees requiring institutional change. It has also highlighted some of the problems encountered in this process and some of the limits on a court's power to reform institutions. During these two years, substantial improvements have occurred in Partlow which have made it safer, more sanitary, and generally more habitable for the residents. But a large disparity still exists between the existing institution and the standards contained in the decree.

Judge Johnson clearly recognized both the need for continued judicial responsibility and the usefulness of a judicially fashioned body-the Human Rights Committee-to assist the court in its task. The Partlow Human Rights Committee served as the "eyes and ears" of the court by monitoring changes in the institution, reporting on these changes, and recommending to the court alternative approaches to implementation.

The PHRC proved to be an effective aid to the court's retention of jurisdiction. The committee's continued access to the court, and its ability to publicize its findings, enabled it to influence the defendants

\footnotetext{
this usually takes place at oral argument and covers changes that occurred between the entry of the lower court judgment and the date of oral argument. See, e.g., DeFunis v. Odegaard, 416 U.S. 312, 315-16 (1974); Transcript of Oral Argument in DeFunis $v$. Odegaard, reprinted in 3 DEFUNIS versus ODEGAARD AND THE UNIVERSITY OF WASHINGTON 1327,1330 (A. Ginger ed. 1974). Nevertheless, because the factual requests in Wyatt went beyond this informal inquiry, it would have been desirable for the Fifth Circuit to instruct the district court to conduct an evidentiary hearing on compliance to supplement the record already in the appellate court. Such a procedure would have served the goal of basing the decision on the current facts of the controversy, and avoided the danger of relying on representations by one party that had not been subject to an adversarial hearing. Indeed, the Fifth Circuit would have been well-advised to request the district court to provide it with periodic progress reports on changes in the institution pursuant to the decree during the pendency of the appeal. This would have enabled it to appraise the changes more accurately, and therefore better assess the feasibility of the decree.

223. Dinsmore Interview, supra note 6; Mathews Interview; Murphy Interview; Wagnon Interview.

224. Dean Interview, supra note 6; Drake Interview.
} 
toward implementation. The vagueness of the committee's powers allowed the court to vary its authority according to changing circumstances. There was a substantial correlation between the PHRC's effectiveness in bringing about improvements in the institution and the willingness of the court to support the efforts of the committee through, for example, the issuance of a show cause order. The committee's effectiveness was limited by its lack of staff, which precluded continual monitoring of the institution; its want of expertise, which made thorough evaluation of the changes difficult; and the resistance of the institutional bureaucracy to outside scrutiny.

The variance which still remains between the standards of the decree and the conditions within the institution results primarily from two factors. First, during the protracted delay in the Fifth Circuit's decision, a "go slow" approach was adopted by the district court. This allowed the defendants to proceed at their own pace in implementing the decree, and discouraged the plaintiffs and amici from insisting on prompt compliance. Second, although state expenditures for mental health have increased enormously, Alabama has yet to make the massive financial commitment required to implement the decree fully. Moreover, the failure of the court or the parties to confront whether the "right to treatment" compels deinstitutionalization and treatment in the least restrictive alternative setting, rather than only institutional reform, has limited implementation to the latter.

Wyatt has shown that the judiciary is capable of achieving fairly broad reforms in existing institutions. However, the implementation of the decree in Wyatt provokes important questions of both a legal and practical nature. The propriety of issuing this type of order depends upon one's view of the proper relationship between the judicial branch and the legislative and executive branches. The efficacy of these orders is ultimately determined by the ability of courts to formulate and enforce such relief. Because Wyatt is only a single case with many unique features, and because its first phase of implementation was restricted by the pendency of an appeal, Wyatt cannot conclusively resolve either of these questions on the separation of powers or the institutional competency of the judiciary. Further study by both judges and scholars is thus necessary to provide more definite conclusions about the process of implementation. In rendering decisions, courts rely on legal precedents established in other cases involving analogous issues. In effectuating those decisions, courts should similarly be able to rely on practical precedents concerning the implementation of judicial decrees. 